Supporting Information

\title{
Atomic-Level Understanding of Effect of Heteroatom Doping of the Cocatalyst on Water-Splitting Activity in AuPd or AuPt Alloy Cluster- Loaded $\mathrm{BaLa}_{4} \mathrm{Ti}_{4} \mathrm{O}_{15}$
}

Wataru Kurashige, ${ }^{1,2}$ Rui Hayashi, ${ }^{1}$ Kosuke Wakamatsu, ${ }^{1}$ Yuki Kataoka, ${ }^{1}$ Sakiat Hossain, ${ }^{1}$ Akihide Iwase, ${ }^{1,2}$ Akihiko Kudo, ${ }^{1,2}$ Seiji Yamazoe, ${ }^{3,}{ }^{*}$ and Yuichi Negishi, ${ }^{1,2,}$

${ }^{1}$ Department of Applied Chemistry, Faculty of Science, Tokyo University of Science, 1-3 Kagurazaka, Shinjuku-ku, Tokyo 162-8601, Japan.

${ }^{2}$ Photocatalysis International Research Center, Tokyo University of Science, 2641 Yamazaki, Noda, Chiba 278-8510, Japan.

${ }^{3}$ Department of Chemistry, Graduate School of Science, Tokyo Metropolitan University, 1-1 Minami-Osawa, Hachiojishi, Tokyo 192-0397, Japan.

Corresponding Author

E-mail: negishi@rs.kagu.tus.ac.jp (Y. Negishi); yamazoe@tmu.ac.jp (S. Yamazoe)

\section{Tables}

Table S1. Adsorption efficiency of the clusters on $\mathrm{BaLa}_{4} \mathrm{Ti}_{4} \mathrm{O}_{15}$.

\begin{tabular}{ccc}
\hline sample & before ligand exchange $^{a}$ & after ligand exchange $^{b}$ \\
\hline $\mathrm{Au}_{25}$ & $5.1 \%^{c}$ & $96.3 \%^{c}$ \\
$\mathrm{Au}_{24} \mathrm{Pd}$ & $7.1 \%^{c}$ & $96.8 \%^{c}$ \\
$\mathrm{Au}_{24} \mathrm{Pt}$ & $16.8 \%^{c}$ & $97.7 \%^{c}$ \\
\hline
\end{tabular}

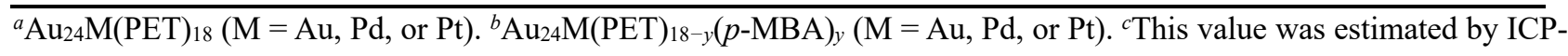
MS.

Table S2. Au $\mathrm{L}_{3}$-edge EXAFS fitting results for $\mathrm{Au}_{24} \mathrm{M}-\mathrm{BaLa}_{4} \mathrm{Ti}_{4} \mathrm{O}_{15}$ and $\mathrm{Au}$ foil.

\begin{tabular}{cccccc}
\hline sample & bond & $\mathbf{C . N .}^{a}$ & $\mathbf{R}(\AA)$ & D.W. & ${ }^{b}$ \\
\hline $\mathrm{Au}_{25}-\mathrm{BaLa}_{4} \mathrm{Ti}_{4} \mathrm{O}_{15}$ & $\mathrm{Au}-\mathrm{Au}$ & $7.1(4)$ & $2.816(34)$ & $0.092(26)$ & 13.3 \\
$\mathrm{Au}_{24} \mathrm{Pd}-\mathrm{BaLa}_{4} \mathrm{Ti}_{4} \mathrm{O}_{15}$ & $\mathrm{Au}-\mathrm{Au}$ & $7.4(4)$ & $2.819(35)$ & $0.095(26)$ & 12.1 \\
$\mathrm{Au}_{24} \mathrm{Pt}-\mathrm{BaLa}_{4} \mathrm{Ti}_{4} \mathrm{O}_{15}$ & $\mathrm{Au}-\mathrm{Au}$ & $7.7(4)$ & $2.814(36)$ & $0.098(26)$ & 14.0 \\
$\mathrm{Au}$ foil & $\mathrm{Au}-\mathrm{Au}$ & $10.9(4)$ & $2.845(25)$ & $0.087(19)$ & 12.4 \\
\hline
\end{tabular}

The numbers in parentheses are the uncertainties, for example, 7.1(4) represents 7.1 \pm 0.4 .

${ }^{a}$ Coordination number. ${ }^{b}$ Debye-Waller factor. 
Table S3. Pd K-edge EXAFS fitting results for $\mathrm{Au}_{24} \mathrm{Pd}-\mathrm{BaLa}_{4} \mathrm{Ti}_{4} \mathrm{O}_{15}$.

\begin{tabular}{cccccc}
\hline sample & bond & C.N. $^{a}$ & $\mathbf{R}(\AA)$ & D.W. $^{b}$ & R factor (\%) $^{b}$ \\
\hline \multirow{2}{*}{$\mathrm{Au}_{24} \mathrm{Pd}-\mathrm{BaLa}_{4} \mathrm{Ti}_{4} \mathrm{O}_{15}$} & $\mathrm{Pd}-\mathrm{S}$ & $1.5(3)$ & $2.238(59)$ & $0.010(6)$ & 15 \\
& $\mathrm{Pd}-\mathrm{Au}$ & $6.8(5)$ & $2.822(44)$ & $0.012(6)$ & \\
\hline
\end{tabular}

The numbers in parentheses are the uncertainties, for example, 1.5(3) represents $1.5 \pm 0.3$.

${ }^{a}$ Coordination number. ${ }^{b}$ Debye-Waller factor.

Table S4. Pt $\mathrm{L}_{3}$-edge EXAFS fitting results for $\mathrm{Au}_{24} \mathrm{Pt}-\mathrm{BaLa}_{4} \mathrm{Ti}_{4} \mathrm{O}_{15}$.

\begin{tabular}{cccccc}
\hline sample & bond & C.N. $^{a}$ & $\mathbf{R}(\mathbf{\AA})$ & D.W. $^{b}$ & R factor (\%) $^{b}$ \\
\hline $\mathrm{Au}_{24} \mathrm{Pt}-\mathrm{BaLa}_{4} \mathrm{Ti}_{4} \mathrm{O}_{15}$ & $\mathrm{Pt}-\mathrm{O}$ & $5.4(3)$ & $2.023(39)$ & $0.085(38)$ & 39 \\
\hline
\end{tabular}

The numbers in parentheses are the uncertainties, for example, 5.4(3) represents 5.4 \pm 0.3 .

${ }^{a}$ Coordination number. ${ }^{b}$ Debye-Waller factors.

Table S5. Au L $\mathrm{L}_{3}$-edge EXAFS fitting results for $\left(\mathrm{Au}_{24} \mathrm{Pt}\right)_{1-3}-\mathrm{Cr}_{2} \mathrm{O}_{3}-\mathrm{BaLa}_{4} \mathrm{Ti}_{4} \mathrm{O}_{15}$.

\begin{tabular}{cccccc}
\hline sample & bond & C.N. $^{a}$ & $\mathbf{R}(\AA)$ & D.W. $^{b}$ & $\begin{array}{c}\text { R factor }^{(\%)} \\
(\mathbf{\%})\end{array}$ \\
\hline$\left(\mathrm{Au}_{24} \mathrm{Pt}\right)_{1-3}-\mathrm{Cr}_{2} \mathrm{O}_{3}-\mathrm{BaLa}_{4} \mathrm{Ti}_{4} \mathrm{O}_{15}$ & $\mathrm{Au}-\mathrm{Au}$ & $7.8(5)$ & $2.830(41)$ & $0.0104(52)$ & 9.8 \\
\hline
\end{tabular}

The numbers in parentheses are the uncertainties, for example, 7.8(5) represents 7.8 \pm 0.5 .

${ }^{a}$ Coordination number. ${ }^{b}$ Debye-Waller factor.

Table S6. Pt $\mathrm{L}_{3}$-edge EXAFS fitting results for $\left(\mathrm{Au}_{24} \mathrm{Pt}\right)_{1-3}-\mathrm{Cr}_{2} \mathrm{O}_{3}-\mathrm{BaLa}_{4} \mathrm{Ti}_{4} \mathrm{O}_{15}$.

\begin{tabular}{cccccc}
\hline sample & bond & C.N. $^{a}$ & $\mathbf{R}(\AA)$ & D.W. $^{b}$ & $\begin{array}{c}\text { R factor } \\
(\%)\end{array}$ \\
\hline$\left(\mathrm{Au}_{24} \mathrm{Pt}\right)_{1-3}-\mathrm{Cr}_{2} \mathrm{O}_{3}-\mathrm{BaLa}_{4} \mathrm{Ti}_{4} \mathrm{O}_{15}$ & $\mathrm{Pt}-\mathrm{O}$ & $3.9(2)$ & $1.939(36)$ & $0.0003(2)$ & 7.4 \\
\hline
\end{tabular}

The numbers in parentheses are the uncertainties, for example, 3.9(2) represents 3.9 \pm 0.2 .

${ }^{a}$ Coordination number. ${ }^{b}$ Debye-Waller factor. 


\section{Additional Figures}

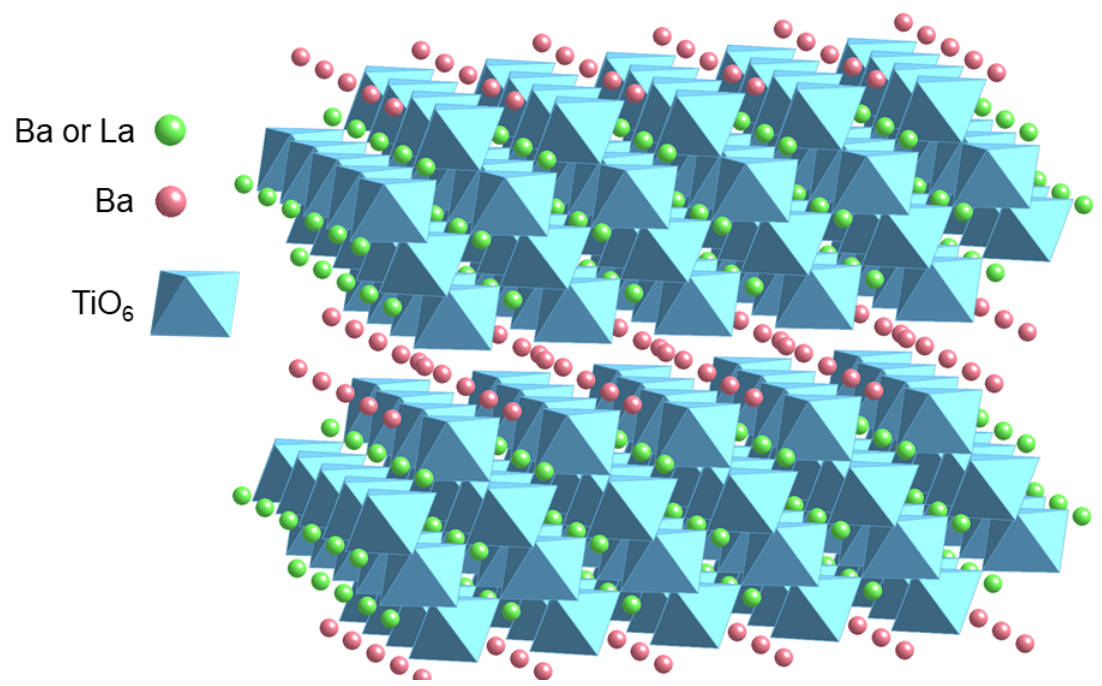

Figure S1. Structure of $\mathrm{BaLa}_{4} \mathrm{Ti}_{4} \mathrm{O}_{15}{ }^{1}$

(a)<smiles>NC(CCC(=O)NC(CS)C(=O)NCC(=O)O)C(=O)O</smiles>

SG (b)<smiles>SCCc1ccccc1</smiles>

PET (c)<smiles>CCCCOC(C)(C)C</smiles>

Figure S2. Geometrical structures of the thiolates used in this work: (a) L-gluthathionate (SG), (b) phenylethanethiolate (PET), and (c) para-mercaptobenzoic acid ( $p$-MBA). 


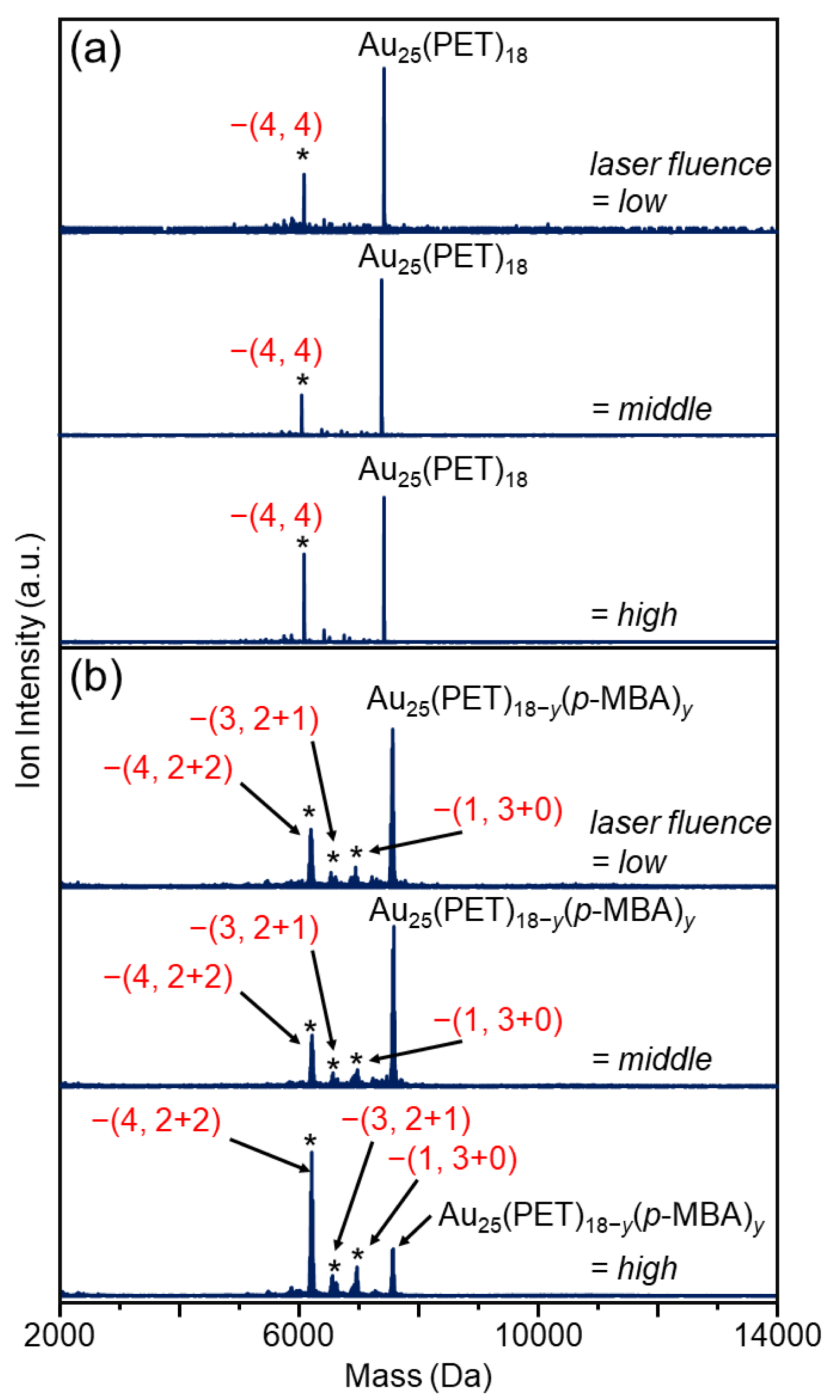

Figure S3. Laser-fluence dependence of the negative-ion MALDI mass spectra of (a) $\mathrm{Au}_{25}(\mathrm{PET})_{18}$ and (b) $\mathrm{Au}_{25}(\mathrm{PET})_{18-y}(p-\mathrm{MBA})_{y}(y=7-15)$. The intensities of the peaks marked with asterisks increase with increasing laser fluence, indicating that these peaks are fragments caused by laser irradiation. In (a), the notation $-(n, m)$ represents $\mathrm{Au}_{25-n}(\mathrm{PET})_{18-m}$. In $(\mathrm{b})$, the notation $-(n, m+l)$ represents $\mathrm{Au}_{25-n}(\mathrm{PET})_{18-m-y}(p-$ MBA) $)_{y-l}$. 


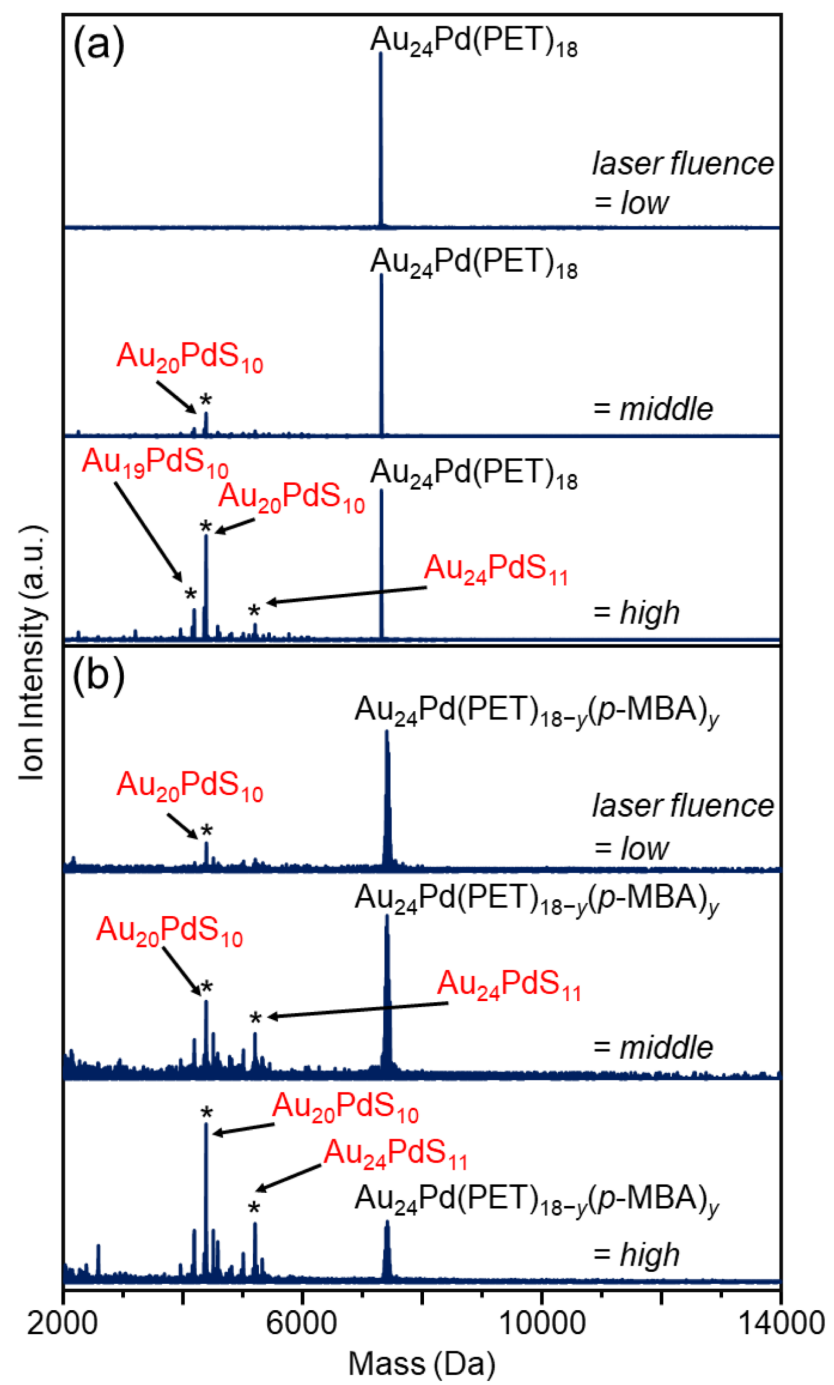

Figure S4. Laser-fluence dependence of the negative-ion MALDI mass spectra of (a) $\mathrm{Au}_{24} \mathrm{Pd}(\mathrm{PET})_{18}$ and (b) $\mathrm{Au}_{24} \mathrm{Pd}(\mathrm{PET})_{18-y}(p-\mathrm{MBA})_{y}(y=1-9)$. The intensities of the peaks marked with asterisks increase with increasing laser fluence, indicating that these peaks are fragments caused by laser irradiation. 


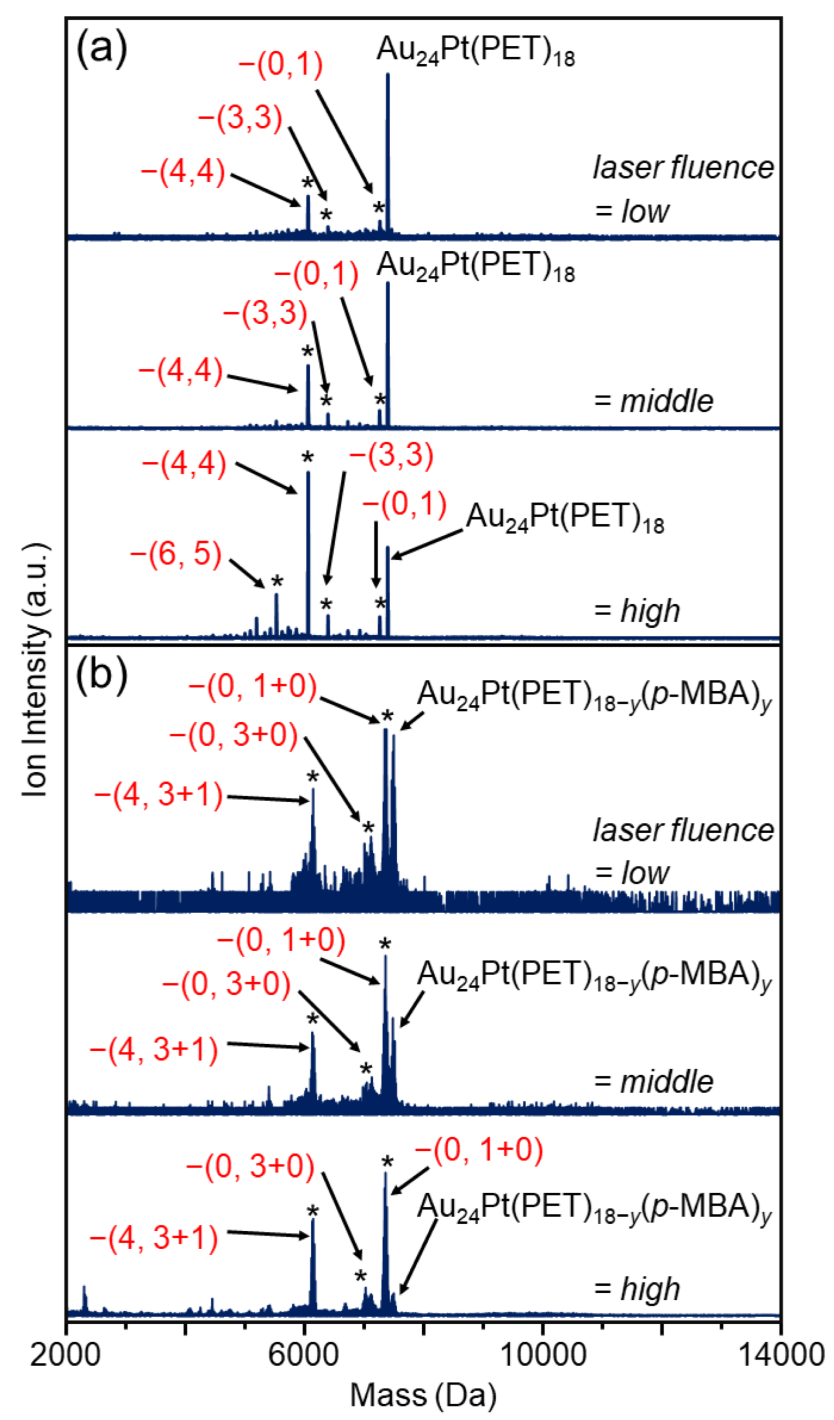

Figure S5. Laser-fluence dependence of the negative-ion MALDI mass spectra of (a) $\mathrm{Au}_{24} \mathrm{Pt}(\mathrm{PET})_{18}$ and (b) $\mathrm{Au}_{24} \mathrm{Pt}(\mathrm{PET})_{18-y}(p-\mathrm{MBA})_{y}(y=3-10)$. The intensities of the peaks marked with asterisks increase with increasing laser fluence, indicating that these peaks are fragments caused by laser irradiation. In (a), the notation $-(n, m)$ represents $\mathrm{Au}_{24-n} \mathrm{Pt}(\mathrm{PET})_{18-m}$. In (b), the notation $-(n, m+l)$ represents $\mathrm{Au}_{24-n} \mathrm{Pt}(\mathrm{PET})_{18-m-y}(p-\mathrm{MBA})_{y-l}$. 


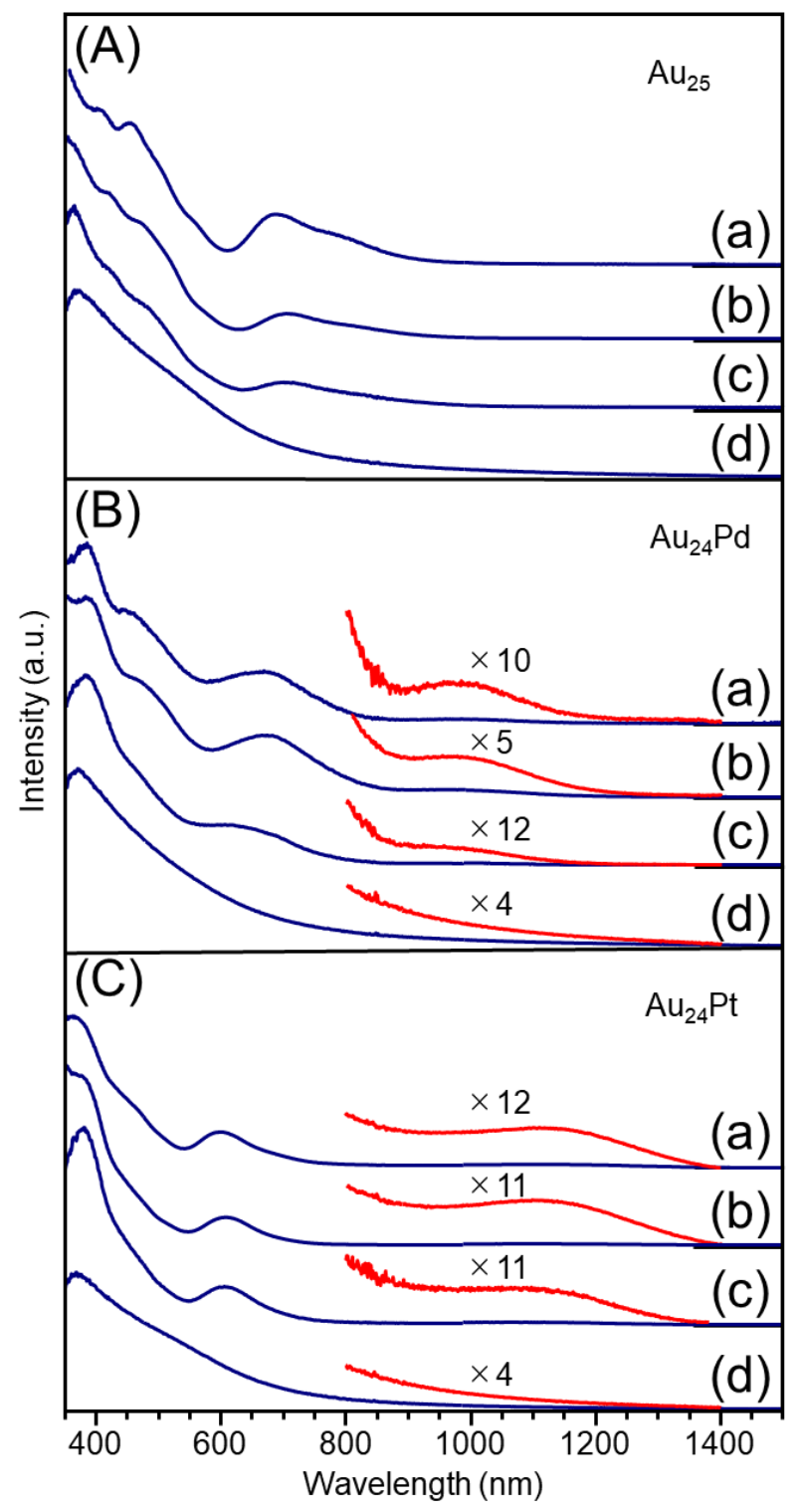

Figure S6. DR spectra of (a) $\mathrm{Au}_{24} \mathrm{M}(\mathrm{PET})_{18}$, (b) $\mathrm{Au}_{24} \mathrm{M}(\mathrm{PET})_{18-y}(p-\mathrm{MBA})_{y}$, (c) $\mathrm{Au}_{24} \mathrm{M}(\mathrm{PET})_{18-y}(p-\mathrm{MBA})_{y}-$ $\mathrm{BaLa}_{4} \mathrm{Ti}_{4} \mathrm{O}_{15}$, and (d) $\mathrm{Au}_{24} \mathrm{M}-\mathrm{BaLa}_{4} \mathrm{Ti}_{4} \mathrm{O}_{15}$ for $\mathrm{M}=$ (A) $\mathrm{Au}$, (B) $\mathrm{Pd}$, and (C) Pt. The DR spectra of $\mathrm{Au}_{24} \mathrm{M}(\mathrm{PET})_{18}$ are similar to those in the literature. ${ }^{2-4}$ 
(A)

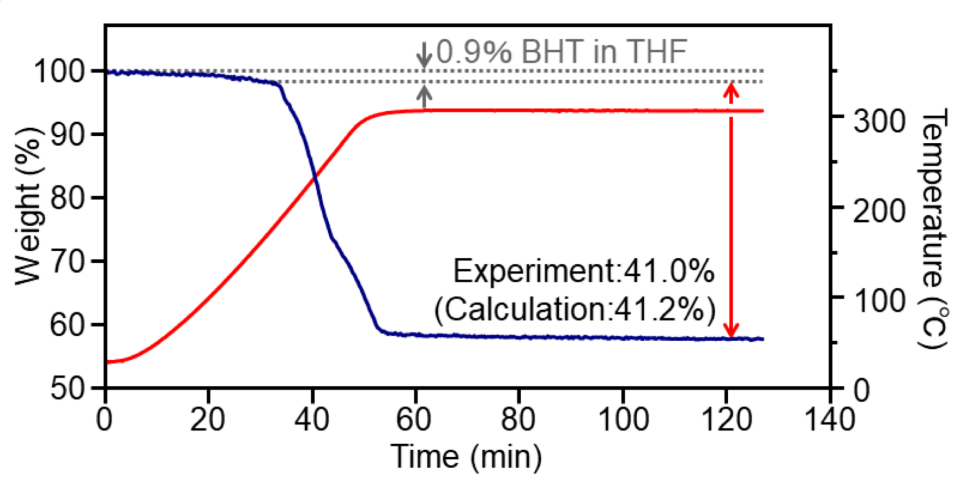

(B)

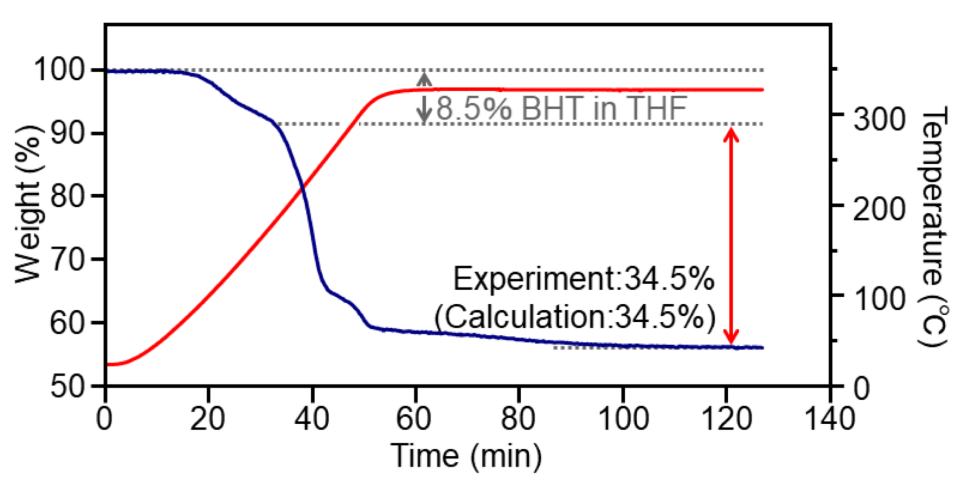

(C)

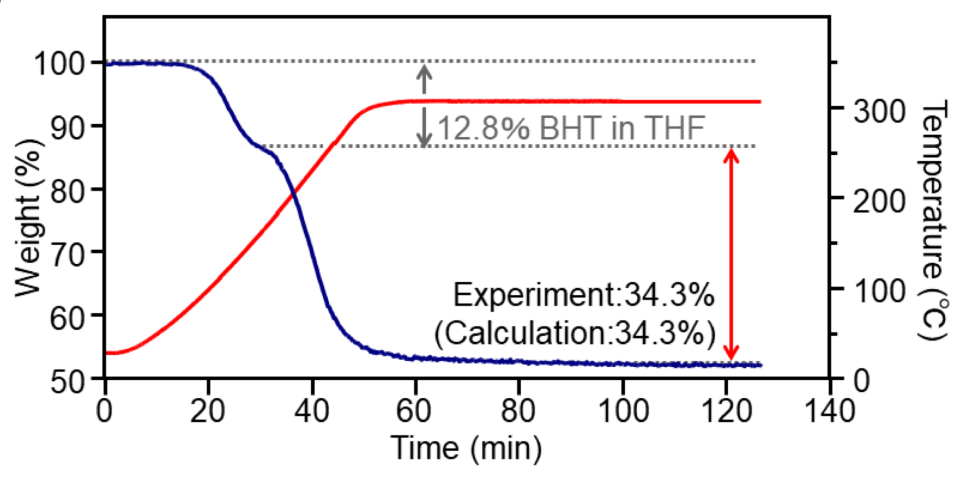

Figure S7. TGA data for (A) $\mathrm{Au}_{25}(\mathrm{PET})_{18-y}(p-\mathrm{MBA})_{y}(y=7-15)$, (B) $\mathrm{Au}_{24} \mathrm{Pd}(\mathrm{PET})_{18-y}(p-\mathrm{MBA})_{y}(y=1-$ 9 ), and (C) $\mathrm{Au}_{24} \mathrm{Pt}(\mathrm{PET})_{18-y}(p-\mathrm{MBA})_{y}(y=3-10)$. The observed weight losses of $41.0 \%, 34.5 \%$, and $34.3 \%$ are consistent with the organic proportions of $\mathrm{Au}_{25}(\mathrm{PET})_{18-y}(p-\mathrm{MBA})_{y}(y=7-15)$ (exactly $\left.\left[\mathrm{Au}_{25}(\mathrm{PET})_{18-y}(p-\mathrm{MBA})_{y}\right]\left[\mathrm{N}\left(\mathrm{C}_{8} \mathrm{H}_{17}\right)_{4}\right]\right), \mathrm{Au}_{24} \mathrm{Pd}(\mathrm{PET})_{18-y}(p-\mathrm{MBA})_{y}(y=1-9)$, and $\mathrm{Au}_{24} \mathrm{Pt}(\mathrm{PET})_{18-y}(p-$ MBA $)_{y}(y=3-10)$, respectively. The average $y$ value estimated by eq (2) in ref 5 on the basis of the mass spectra shown in Figure 4 was used in these calculations. The decrease of the weight at low temperature $\left(<170{ }^{\circ} \mathrm{C}\right)$ is because of the stabilizer included in THF (dibutylhydroxytoluene; BHT). These results indicate that the ligands included in $\mathrm{Au}_{25}(\mathrm{PET})_{18-y}(p-\mathrm{MBA})_{y}, \mathrm{Au}_{24} \mathrm{Pd}(\mathrm{PET})_{18-y}(p-\mathrm{MBA})_{y}$, and $\mathrm{Au}_{24} \operatorname{Pt}(\mathrm{PET})_{18-y}(p-\mathrm{MBA})_{y}$ can be eliminated during calcination at $300{ }^{\circ} \mathrm{C}$ for $80 \mathrm{~min}$. 


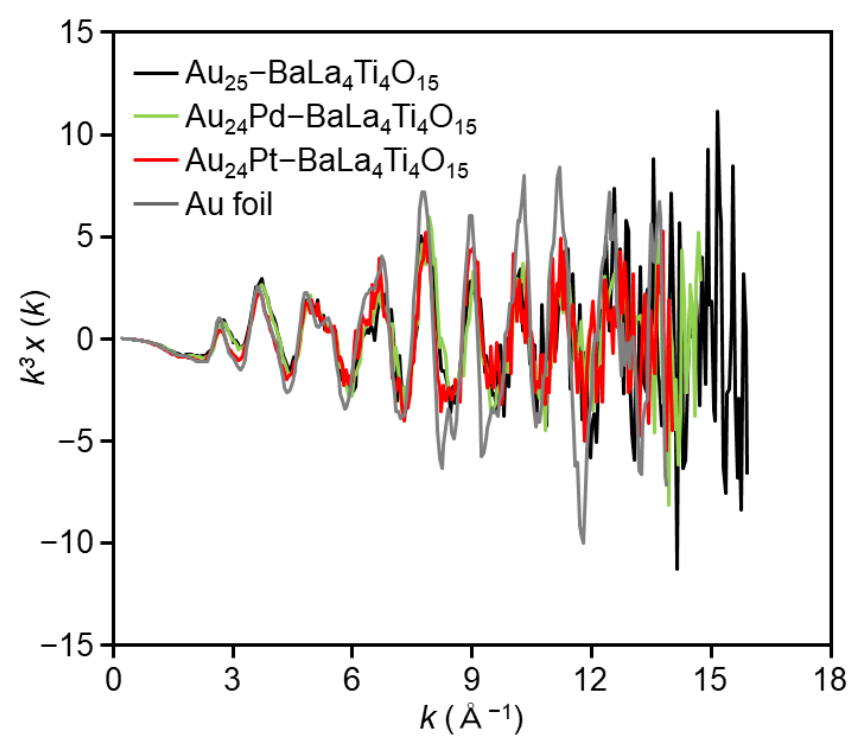

Figure S8. $\mathrm{Au} \mathrm{L}_{3}$-edge EXAFS spectra of $\mathrm{Au}_{25}-\mathrm{BaLa}_{4} \mathrm{Ti}_{4} \mathrm{O}_{15}, \mathrm{Au}_{24} \mathrm{Pd}-\mathrm{BaLa}_{4} \mathrm{Ti}_{4} \mathrm{O}_{15}$, and $\mathrm{Au}_{24} \mathrm{Pt}-$ $\mathrm{BaLa}_{4} \mathrm{Ti}_{4} \mathrm{O}_{15}$ together with that of $\mathrm{Au}$ foil.

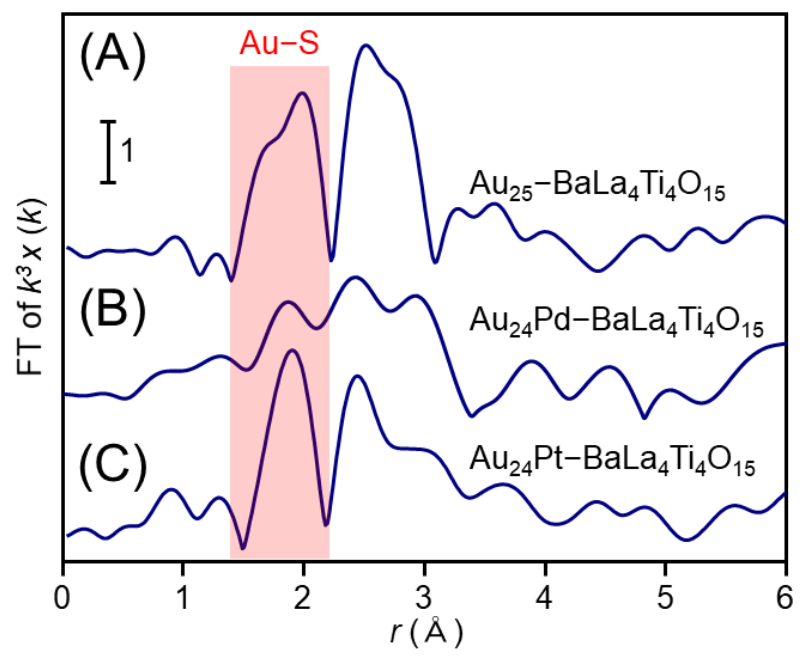

Figure S9. $\mathrm{Au} \mathrm{L} \mathrm{L}_{3}$-edge FT-EXAFS spectra of (A) $\mathrm{Au}_{25}-\mathrm{BaLa}_{4} \mathrm{Ti}_{4} \mathrm{O}_{15}$, (B) $\mathrm{Au}_{24} \mathrm{Pd}-\mathrm{BaLa}_{4} \mathrm{Ti}_{4} \mathrm{O}_{15}$, and (C) $\mathrm{Au}_{24} \mathrm{Pt}-\mathrm{BaLa}_{4} \mathrm{Ti}_{4} \mathrm{O}_{15}$ obtained by calcination at $250{ }^{\circ} \mathrm{C}$ (Table S5). In the FT-EXAFS spectra, the peak assigned to the $\mathrm{Au}-\mathrm{S}$ bond is observed, indicating that $250{ }^{\circ} \mathrm{C}$ is not high enough for complete elimination of all of the ligands of $\mathrm{Au}_{24} \mathrm{Pt}(\mathrm{PET})_{18-y}(p-\mathrm{MBA})_{y}$. These results are consistent with the TGA data shown in Figure S7. 


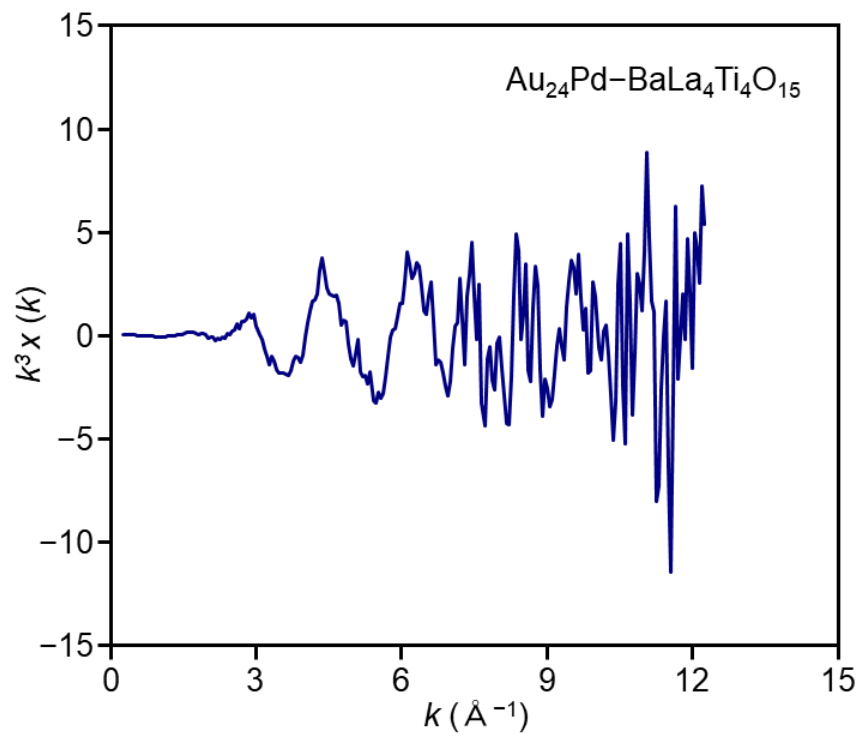

Figure S10. Pd K-edge EXAFS spectrum of $\mathrm{Au}_{24} \mathrm{Pd}-\mathrm{BaLa}_{4} \mathrm{Ti}_{4} \mathrm{O}_{15}$.

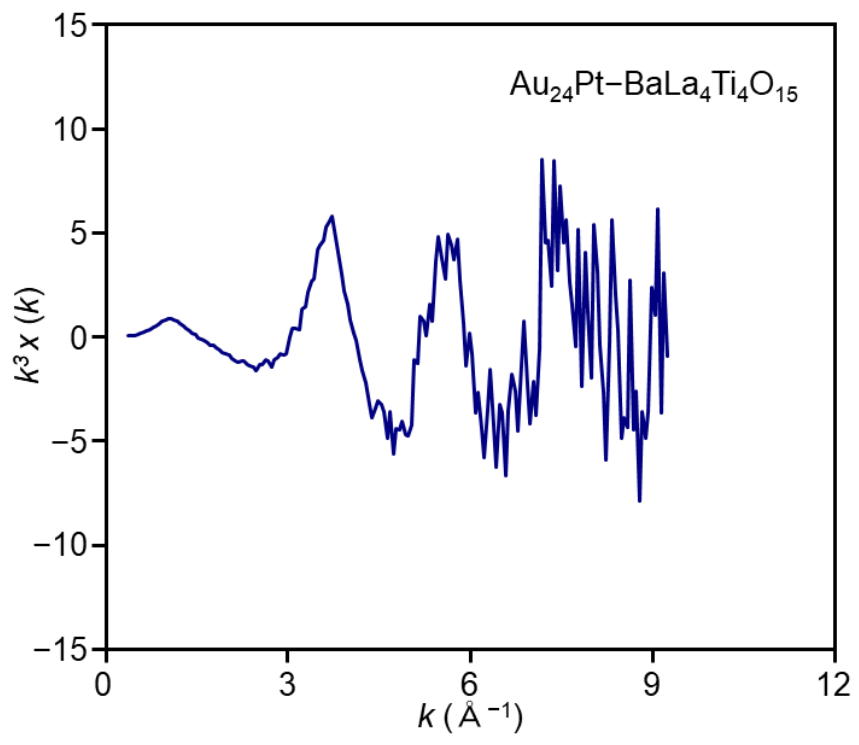

Figure S11. $\mathrm{Pt} \mathrm{L}_{3}$-edge EXAFS spectrum of $\mathrm{Au}_{24} \mathrm{Pt}-\mathrm{BaLa}_{4} \mathrm{Ti}_{4} \mathrm{O}_{15}$. 


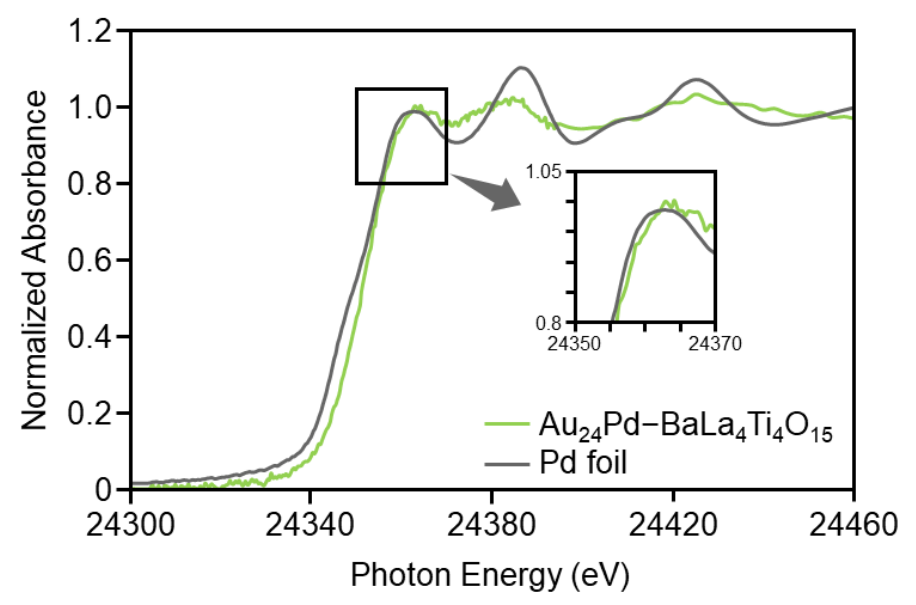

Figure S12. Pd K-edge XANES spectrum of $\mathrm{Au}_{24} \mathrm{Pd}-\mathrm{BaLa}_{4} \mathrm{Ti}_{4} \mathrm{O}_{15}$ together with that of $\mathrm{Pd}$ foil. The whiteline intensity of $\mathrm{Au}_{24} \mathrm{Pd}-\mathrm{BaLa}_{4} \mathrm{Ti}_{4} \mathrm{O}_{15}$ is slightly higher than that of $\mathrm{Pd}$ foil. This result shows that the electron density of the $\mathrm{Pd} 5 \mathrm{~d}$ orbital of $\mathrm{Au}_{24} \mathrm{Pd}-\mathrm{BaLa}_{4} \mathrm{Ti}_{4} \mathrm{O}_{15}$ is lower than that of $\mathrm{Pd}$ foil, indicating that the d-hole density is higher. This phenomenon is considered to be because of charge transfer from Pd to $\mathrm{Au}$ and $\mathrm{S}$.

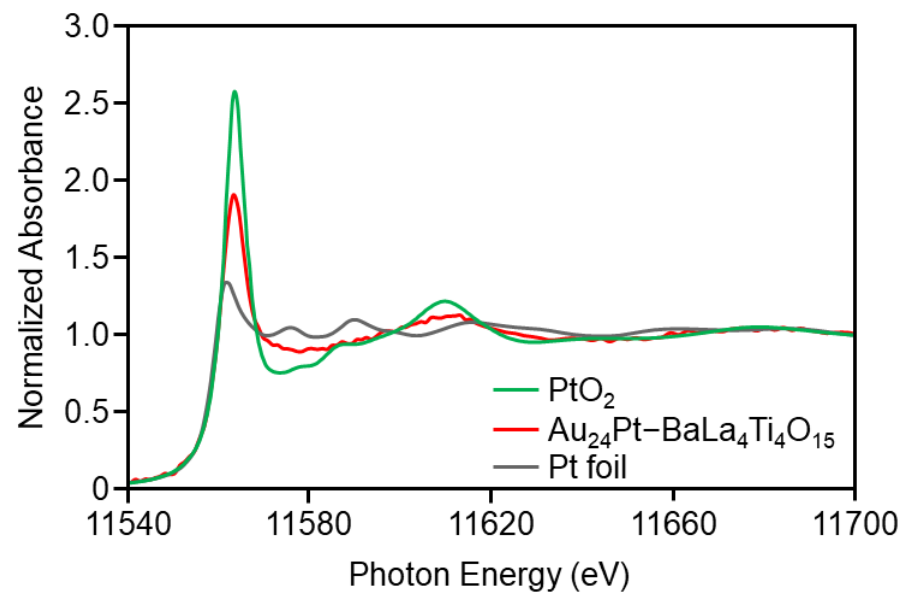

Figure S13. $\mathrm{Pt} \mathrm{L}_{3}$-edge XANES spectrum of $\mathrm{Au}_{24} \mathrm{Pt}-\mathrm{BaLa}_{4} \mathrm{Ti}_{4} \mathrm{O}_{15}$ together with those of $\mathrm{Pt}$ foil and $\mathrm{PtO}_{2}$ powder. The white-line intensity of $\mathrm{Au}_{24} \mathrm{Pt}-\mathrm{BaLa}_{4} \mathrm{Ti}_{4} \mathrm{O}_{15}$ is higher than that of $\mathrm{Pt}$ foil. This result shows that the electron density of the Pt $5 \mathrm{~d}$ orbital of $\mathrm{Au}_{24} \mathrm{Pt}-\mathrm{BaLa}_{4} \mathrm{Ti}_{4} \mathrm{O}_{15}$ is lower than that of $\mathrm{Pt}$ foil and similar to that of $\mathrm{PtO}_{2}$ powder. These results indicate that the charge state of $\mathrm{Pt}$ in $\mathrm{Au}_{24} \mathrm{Pt}-\mathrm{BaLa}_{4} \mathrm{Ti}_{4} \mathrm{O}_{15}$ is similar to that of $\mathrm{Pt}$ in $\mathrm{PtO}_{2}$ powder. 
(a) $\mathrm{Au}_{25}(\mathrm{PET})_{18-y}(p-\mathrm{MBA})_{y}$

(a) $-\mathrm{BaLa}_{4} \mathrm{TT}_{4} \mathrm{O}_{15}$

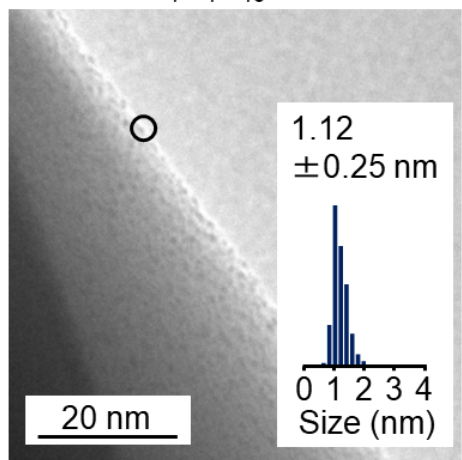

(b) $\mathrm{Au}_{25}-\mathrm{BaLa}_{4} \mathrm{Ti}_{4} \mathrm{O}_{15}$

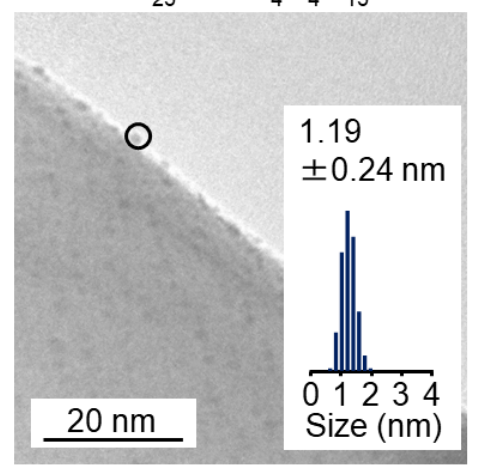

Figure S14. TEM images and particle-size distributions of (a) $\mathrm{Au}_{25}(\mathrm{PET})_{18-y}(p-\mathrm{MBA})_{y}-\mathrm{BaLa}_{4} \mathrm{Ti}_{4} \mathrm{O}_{15}$ and (b) $\mathrm{Au}_{25}-\mathrm{BaLa}_{4} \mathrm{Ti}_{4} \mathrm{O}_{15}$ loaded with a small amount of $\mathrm{Au}(\sim 0.005 \mathrm{wt} \% \mathrm{Au})$. The metal clusters are surrounded by the black circles. It is expected that aggregation of $\mathrm{Au}_{25}$ rarely occurs on the surface of $\mathrm{BaLa}_{4} \mathrm{Ti}_{4} \mathrm{O}_{15}$ under these experimental conditions. The estimated size distributions are relatively similar to those in the samples of Figure $6 \mathrm{~A}(\mathrm{~d})$, Figure $6 \mathrm{~B}(\mathrm{~d})$, and Figure $6 \mathrm{C}(\mathrm{d})$. These results suggest that aggregation of the metal clusters does not occur in the samples of Figure 6A(d), Figure 6B(d), and Figure $6 \mathrm{C}(\mathrm{d})$.

(A) $\mathrm{Au}_{25}-\mathrm{BaLa}_{4} \mathrm{Ti}_{4} \mathrm{O}_{15}$

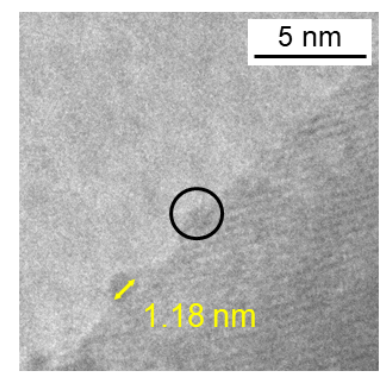

(B) $\mathrm{Au}_{24} \mathrm{Pd}-\mathrm{BaLa}_{4} \mathrm{Ti}_{4} \mathrm{O}_{15}$

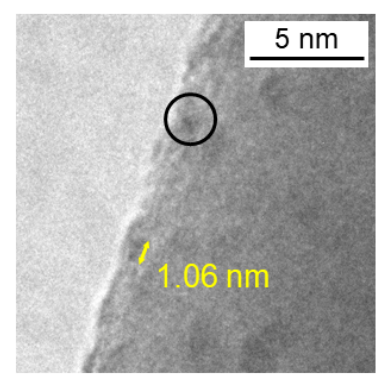

(C) $\mathrm{Au}_{24} \mathrm{Pt}-\mathrm{BaLa}_{4} \mathrm{Ti}_{4} \mathrm{O}_{15}$

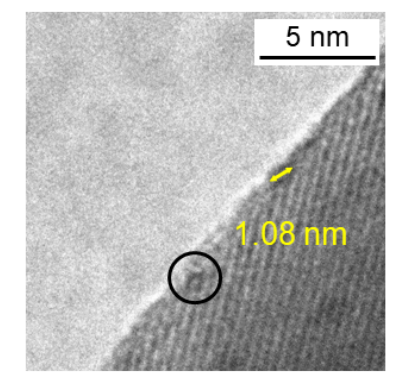

Figure S15. Representative HR-TEM images of (A) $\mathrm{Au}_{25}-\mathrm{BaLa}_{4} \mathrm{Ti}_{4} \mathrm{O}_{15}$, (B) $\mathrm{Au}_{24} \mathrm{Pd}-\mathrm{BaLa}_{4} \mathrm{Ti}_{4} \mathrm{O}_{15}$, and (C) $\mathrm{Au}_{24} \mathrm{Pt}-\mathrm{BaLa}_{4} \mathrm{Ti}_{4} \mathrm{O}_{15}$ obtained by calcination at $300{ }^{\circ} \mathrm{C}$. The metal clusters are surrounded by the black circles. The diameters of the particles in these samples increase in the order $\mathrm{Au}_{24} \mathrm{Pd}-\mathrm{BaLa}_{4} \mathrm{Ti}_{4} \mathrm{O}_{15}(1.06$ $\mathrm{nm}) \approx \mathrm{Au}_{24} \mathrm{Pt}-\mathrm{BaLa}_{4} \mathrm{Ti}_{4} \mathrm{O}_{15}(1.08 \mathrm{~nm})<\mathrm{Au}_{25}-\mathrm{BaLa}_{4} \mathrm{Ti}_{4} \mathrm{O}_{15}(1.18 \mathrm{~nm})$. This is consistent with the results in Figure $6 \mathrm{~A}(\mathrm{~d}), 6 \mathrm{~B}(\mathrm{~d})$, and $6 \mathrm{C}(\mathrm{d})$. 
(a)

side view

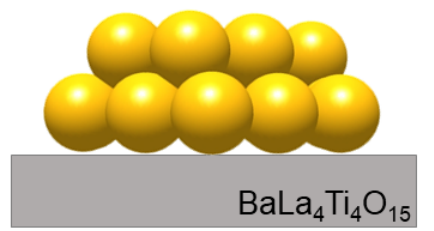

top view

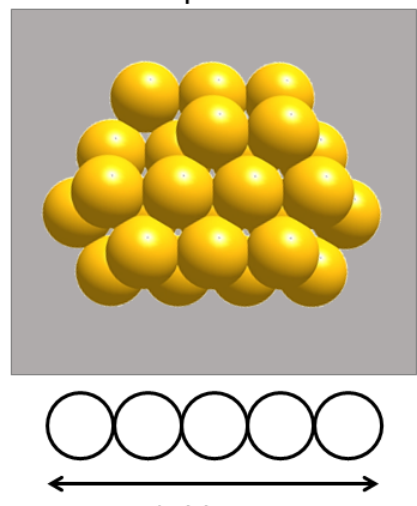

$1.44 \mathrm{~nm}$

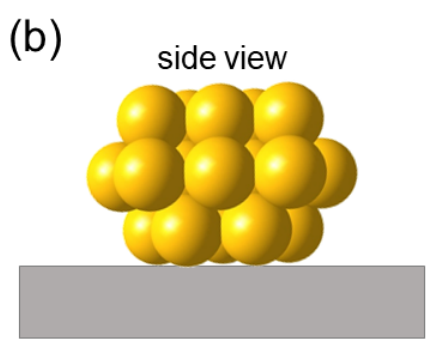

top view

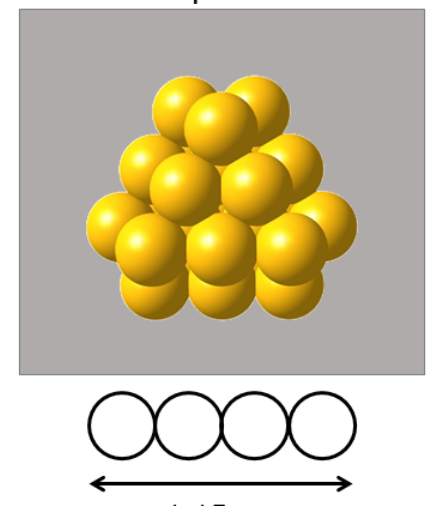

$1.15 \mathrm{~nm}$

Figure S16. Proposed geometrical structures and calculated diameters of the loaded metal clusters: (a) bilayer and (b) three-layer structures. Both of the diameters of the metal clusters in $\mathrm{Au}_{24} \mathrm{Pd}-\mathrm{BaLa}_{4} \mathrm{Ti}_{4} \mathrm{O}_{15}$ (Figure $6 \mathrm{~B}(\mathrm{~d})$ ) and $\mathrm{Au}_{24} \mathrm{Pt}-\mathrm{BaLa}_{4} \mathrm{Ti}_{4} \mathrm{O}_{15}$ (Figure $6 \mathrm{C}(\mathrm{d})$ ) are $1.11 \pm 0.19 \mathrm{~nm}$, suggesting that $\mathrm{Au}_{24} \mathrm{Pd}$ and $\mathrm{Au}_{24} \mathrm{Pt}$ have three-dimensional structures like (b). The diameter of the metal cluster in $\mathrm{Au}_{25}-\mathrm{BaLa}_{4} \mathrm{Ti}_{4} \mathrm{O}_{15}$ (Figure 6A(d)) is $1.24 \pm 0.21 \mathrm{~nm}$, suggesting that the $\mathrm{Au}_{25}$ clusters have a more flat structure, like (a), or are a mixture of three-dimensional and flat structures.

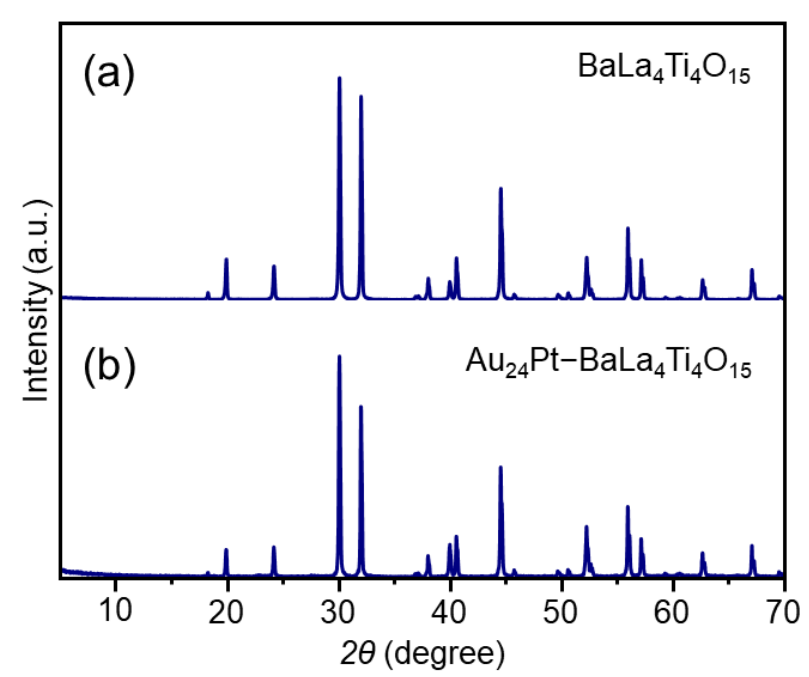

Figure S17. Example of XRD patterns; (a) $\mathrm{BaLa}_{4} \mathrm{Ti}_{4} \mathrm{O}_{15}$ and (b) $\mathrm{Au}_{24} \mathrm{Pt}-\mathrm{BaLa}_{4} \mathrm{Ti}_{4} \mathrm{O}_{15}$. The result did not give useful information on the loaded $\mathrm{Au}_{24} \mathrm{M}\left(\mathrm{M}=\mathrm{Au}, \mathrm{Pd}\right.$, or Pt) because the $\mathrm{Au}_{24} \mathrm{M}$ was loaded on $\mathrm{BaLa}_{4} \mathrm{Ti}_{4} \mathrm{O}_{15}$ with only $\sim 0.1 \mathrm{wt} \% \mathrm{Au}$ to obtain the highest water-splitting activity in this study. Further loading led to the aggregation of the $\mathrm{Au}_{24} \mathrm{M}$ on $\mathrm{BaLa}_{4} \mathrm{Ti}_{4} \mathrm{O}_{15}$. 

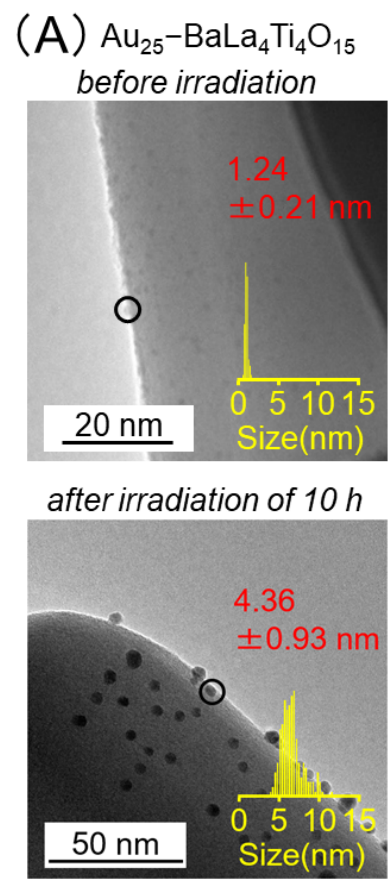

(B) $\mathrm{Au}_{24} \mathrm{Pd}-\mathrm{BaLa}_{4} \mathrm{Ti}_{4} \mathrm{O}_{15}$ before irradiation

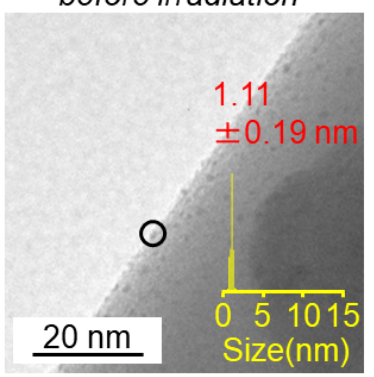

after irradiation of $10 \mathrm{~h}$

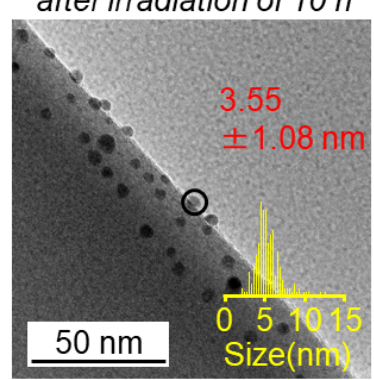

(C) $\mathrm{Au}_{24} \mathrm{Pt}-\mathrm{BaLa}_{4} \mathrm{Ti}_{4} \mathrm{O}_{15}$ before irradiation

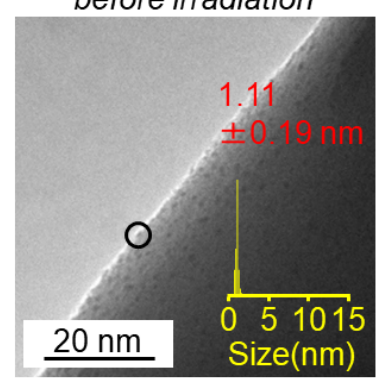

after irradiation of $10 \mathrm{~h}$

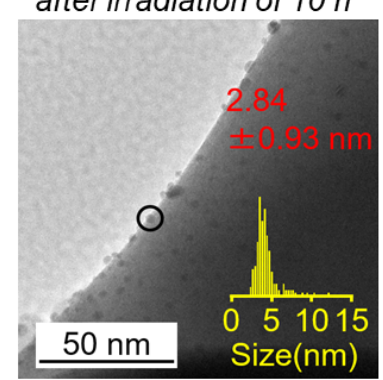

Figure S18. TEM images of (A) $\mathrm{Au}_{25}-\mathrm{BaLa}_{4} \mathrm{Ti}_{4} \mathrm{O}_{15}$, (B) $\mathrm{Au}_{24} \mathrm{Pd}-\mathrm{BaLa}_{4} \mathrm{Ti}_{4} \mathrm{O}_{15}$, and (C) $\mathrm{Au}_{24} \mathrm{Pt}-$ $\mathrm{BaLa}_{4} \mathrm{Ti}_{4} \mathrm{O}_{15}$ before (top) and after (bottom) UV light irradiation of $10 \mathrm{~h}$. The metal clusters are surrounded by the black circles. Aggregation of the metal clusters by UV light irradiation is suppressed in $\mathrm{Au}_{24} \mathrm{Pt}-$ $\mathrm{BaLa}_{4} \mathrm{Ti}_{4} \mathrm{O}_{15}$ (C) compared with that in $\mathrm{Au}_{25}-\mathrm{BaLa}_{4} \mathrm{Ti}_{4} \mathrm{O}_{15}$ (A) and $\mathrm{Au}_{24} \mathrm{Pd}-\mathrm{BaLa}_{4} \mathrm{Ti}_{4} \mathrm{O}_{15}$ (B).

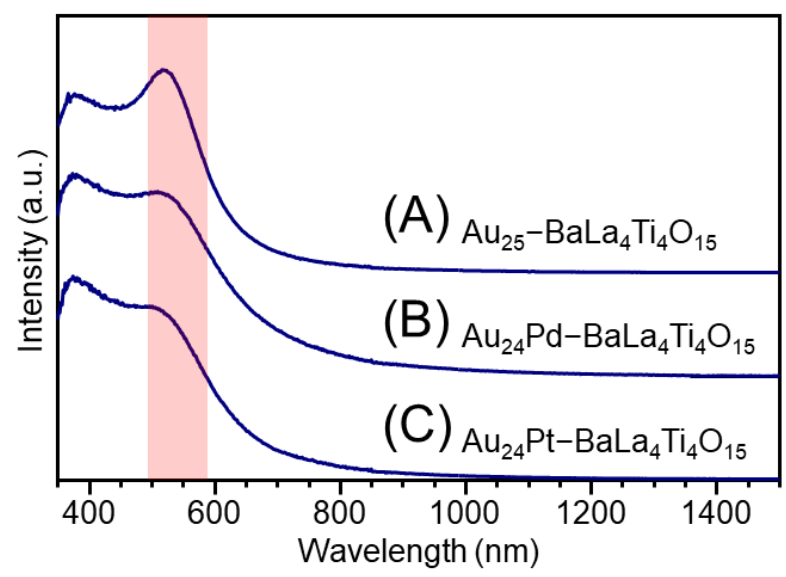

Figure S19. DR spectra of (A) $\mathrm{Au}_{25}-\mathrm{BaLa}_{4} \mathrm{Ti}_{4} \mathrm{O}_{15}$, (B) $\mathrm{Au}_{24} \mathrm{Pd}-\mathrm{BaLa}_{4} \mathrm{Ti}_{4} \mathrm{O}_{15}$, and (C) $\mathrm{Au}_{24} \mathrm{Pt}-\mathrm{BaLa}_{4} \mathrm{Ti}_{4} \mathrm{O}_{15}$ after UV light irradiation of $10 \mathrm{~h}$. The pink region indicates the peak position assigned to surface plasmon resonance. The intensity of the peak in this region is suppressed in the spectrum of $\mathrm{Au}_{24} \mathrm{Pt}-\mathrm{BaLa}_{4} \mathrm{Ti}_{4} \mathrm{O}_{15}$ (C) compared with those in $\mathrm{Au}_{25}-\mathrm{BaLa}_{4} \mathrm{Ti}_{4} \mathrm{O}_{15}$ (A) and $\mathrm{Au}_{24} \mathrm{Pd}-\mathrm{BaLa}_{4} \mathrm{Ti}_{4} \mathrm{O}_{15}$ (B), indicating that aggregation of the metal clusters by $\mathrm{UV}$ light irradiation is suppressed in $\mathrm{Au}_{24} \mathrm{Pt}-\mathrm{BaLa}_{4} \mathrm{Ti}_{4} \mathrm{O}_{15}$ compared with in $\mathrm{Au}_{25}-\mathrm{BaLa}_{4} \mathrm{Ti}_{4} \mathrm{O}_{15}$ and $\mathrm{Au}_{24} \mathrm{Pd}-\mathrm{BaLa}_{4} \mathrm{Ti}_{4} \mathrm{O}_{15}$. 

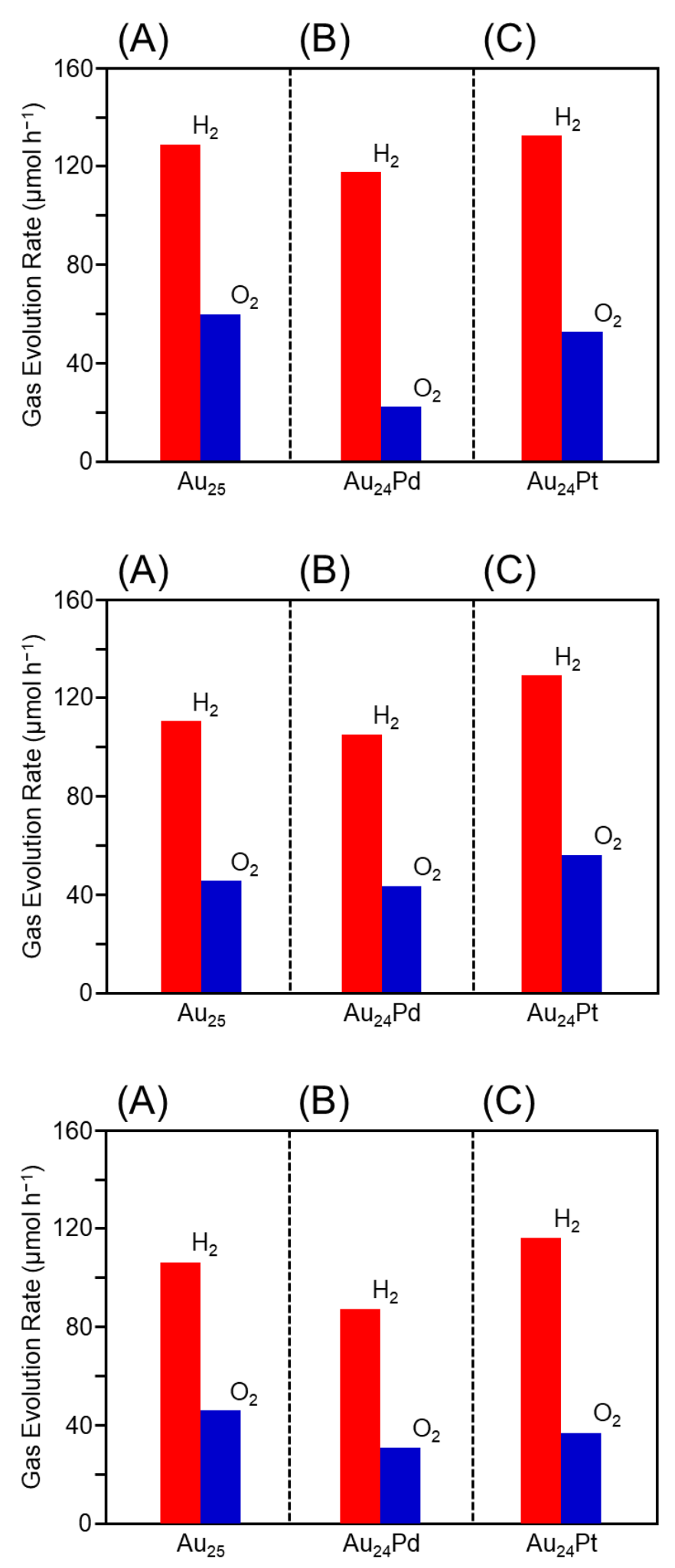

Figure S20. Rates of photocatalytic generation of $\mathrm{H}_{2}$ and $\mathrm{O}_{2}$ by water splitting with $\mathrm{Au}_{24} \mathrm{M}-\mathrm{BaLa}_{4} \mathrm{Ti}_{4} \mathrm{O}_{15}$ for $\mathrm{M}=$ (A) $\mathrm{Au}$, (B) Pd, and (C) Pt obtained using three different experiments. The activity of the sample varied depending on the experiment. However, the relation of the activity of $\mathrm{Au}_{24} \mathrm{M}-\mathrm{BaLa}_{4} \mathrm{Ti}_{4} \mathrm{O}_{15}$ was always the relation shown in Figure 13. 


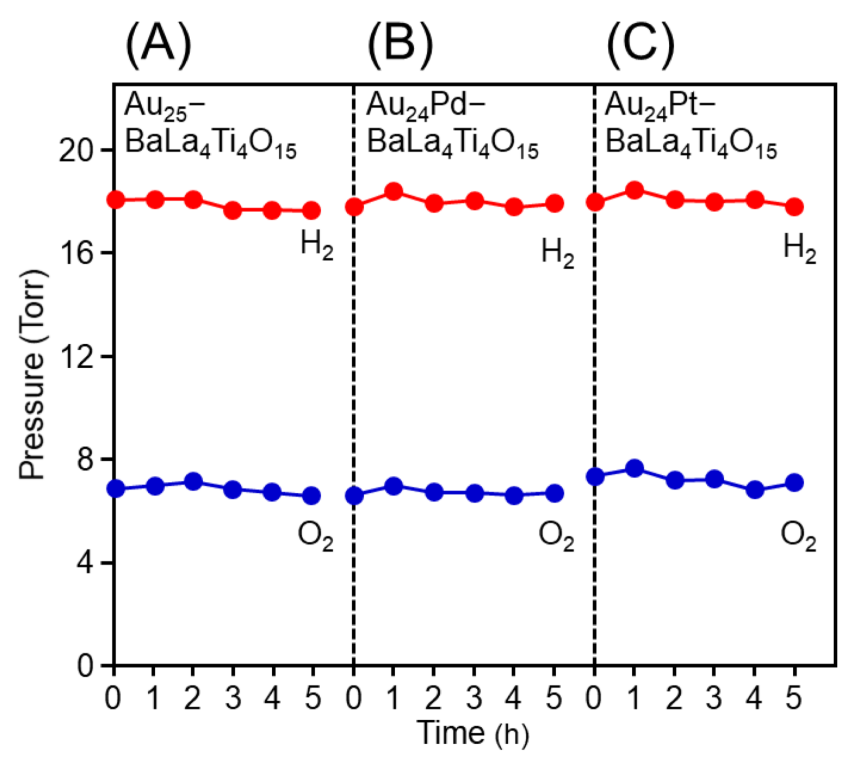

Figure S21. Back reaction between $\mathrm{H}_{2}$ and $\mathrm{O}_{2}$ to produce $\mathrm{H}_{2} \mathrm{O}$ in the gas phase in the dark over (A) $\mathrm{Au}_{25}-$ $\mathrm{BaLa}_{4} \mathrm{Ti}_{4} \mathrm{O}_{15}$, (B) $\mathrm{Au}_{24} \mathrm{Pd}-\mathrm{BaLa}_{4} \mathrm{Ti}_{4} \mathrm{O}_{15}$, and (C) $\mathrm{Au}_{24} \mathrm{Pt}-\mathrm{BaLa}_{4} \mathrm{Ti}_{4} \mathrm{O}_{15}$. These experiments were performed using a gas-tight circulation system with a dead volume of $400-500 \mathrm{~mL}$. In these experiments, $100 \mathrm{mg}$ of photocatalyst was used for each measurement. These results indicate that the back reaction between $\mathrm{H}_{2}$ and $\mathrm{O}_{2}$ does not occur over $\mathrm{Au}_{25}-\mathrm{BaLa}_{4} \mathrm{Ti}_{4} \mathrm{O}_{15}, \mathrm{Au}_{24} \mathrm{Pd}-\mathrm{BaLa}_{4} \mathrm{Ti}_{4} \mathrm{O}_{15}$, and $\mathrm{Au}_{24} \mathrm{Pt}-\mathrm{BaLa}_{4} \mathrm{Ti}_{4} \mathrm{O}_{15}$, and therefore this reaction is not related to the rate of $\mathrm{H}_{2}$ evolution in the water-splitting reaction over $\mathrm{Au}_{25}-\mathrm{BaLa}_{4} \mathrm{Ti}_{4} \mathrm{O}_{15}$, $\mathrm{Au}_{24} \mathrm{Pd}-\mathrm{BaLa}_{4} \mathrm{Ti}_{4} \mathrm{O}_{15}$, and $\mathrm{Au}_{24} \mathrm{Pt}-\mathrm{BaLa}_{4} \mathrm{Ti}_{4} \mathrm{O}_{15}$.

(a)

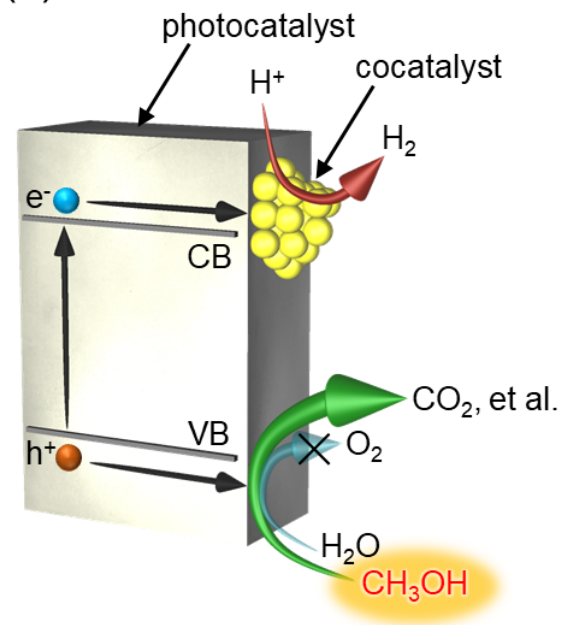

(b)

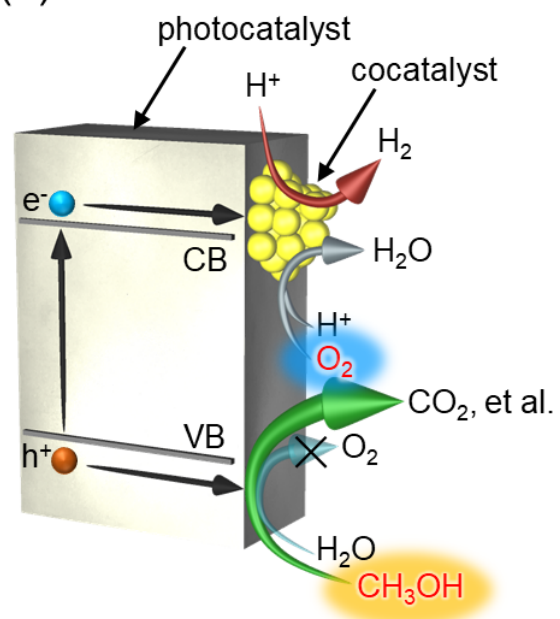

Figure S22. Schematics of photocatalytic $\mathrm{H}_{2}$ evolution using methanol as a sacrificial reagent under a flow of (a) Ar gas (namely, without $\mathrm{O}_{2}$ in the reaction system) and (b) a 7:3 mixture of Ar to air (namely, with $\mathrm{O}_{2}$ in the reaction system) (see Section 4.3). 

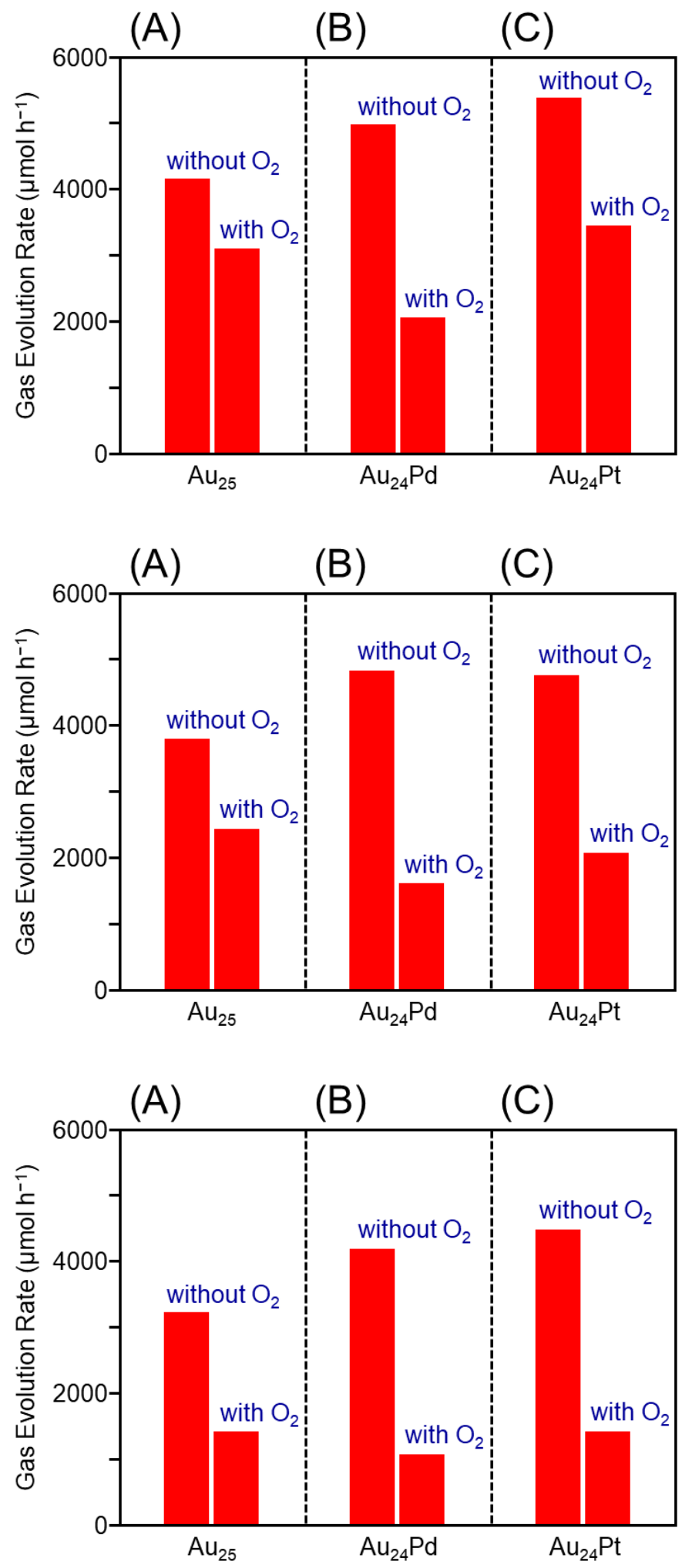

Figure S23. Rates of photocatalytic generation of $\mathrm{H}_{2}$ by $\mathrm{Au}_{24} \mathrm{M}-\mathrm{BaLa}_{4} \mathrm{Ti}_{4} \mathrm{O}_{15}(\mathrm{M}=(\mathrm{A}) \mathrm{Au}$, (B) $\mathrm{Pd}$, and (C) Pt) using methanol as a sacrificial reagent under a flow of Ar gas (labeled "without $\mathrm{O}_{2}$ ", Figure S22(a)) or a 7:3 mixture of Ar to air (labeled "with $\mathrm{O}_{2}$ ", Figure $\mathrm{S} 22(\mathrm{~b})$ ). In this experimental condition, $\mathrm{O}_{2}$ is not generated by light irradiation. The activity of the sample varied depending on the experiment. However, the relation of the activity of $\mathrm{Au}_{24} \mathrm{M}-\mathrm{BaLa}_{4} \mathrm{Ti}_{4} \mathrm{O}_{15}$ was always the relation shown in Figure 14. 


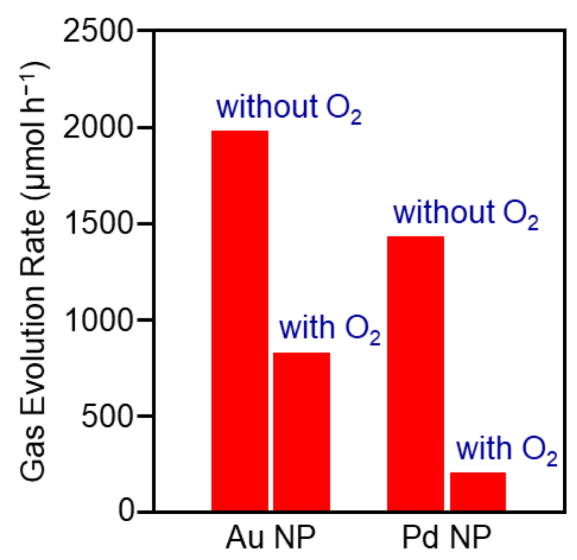

Figure S24. Comparison of the rates of photocatalytic evolution of $\mathrm{H}_{2}$ using methanol as a sacrificial reagent under a flow of Ar gas (labeled "without $\mathrm{O}_{2}$ ", Figure S22(a)) or a 7:3 mixture of Ar to air (labeled "with $\mathrm{O}_{2}$ ", Figure $\left.\mathrm{S} 22(\mathrm{~b})\right)$ by Au nanoparticles $\left(\mathrm{Au}_{\mathrm{NP}}, 7.18 \pm 1.65 \mathrm{~nm}\right)$ and Pd nanoparticles $\left(\mathrm{Pd}_{\mathrm{NP}}, 3.03 \pm\right.$ $0.78 \mathrm{~nm}$ ). This result indicates that (1) Au is a more efficient element for $\mathrm{H}_{2}$ evolution than $\mathrm{Pd}$ and (2) the $\mathrm{O}_{2}$ photoreduction reaction more easily occurs on $\mathrm{Pd}$ than $\mathrm{Au}$. 


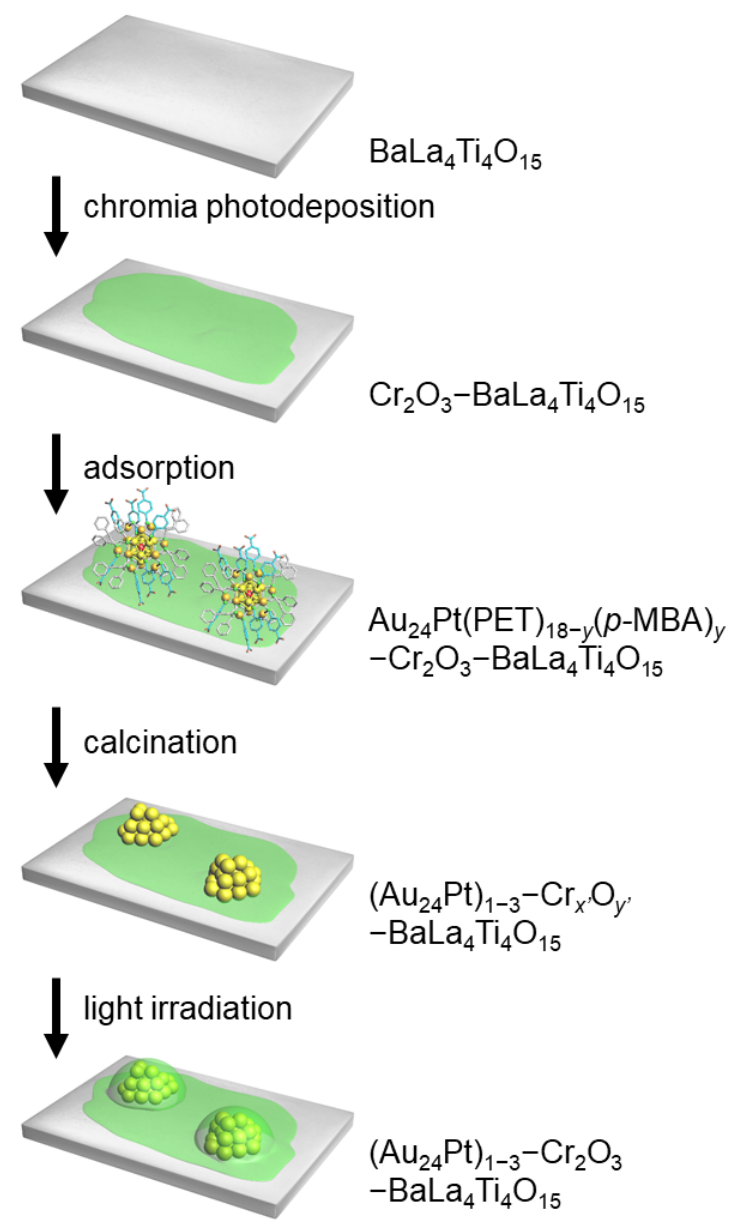

Figure S25. Procedure of $\mathrm{Cr}_{2} \mathrm{O}_{3}$ shell formation used in this work (see Section 4.3). In our previous study of $\mathrm{Au}_{25}-\mathrm{Cr}_{2} \mathrm{O}_{3}-\mathrm{BaLa}_{4} \mathrm{Ti}_{4} \mathrm{O}_{15}$ using $\mathrm{Au}_{25}(\mathrm{SG})_{18}$ as the precursor, ${ }^{6} \mathrm{Au}_{25}$ was embedded into the chromium oxide shell during calcination by the SMSI effect. However, in this study, the metal clusters were not covered by a chromium-oxide shell during the calcination process. In this study, slight aggregation of $\mathrm{Au}_{24} \mathrm{Pt}\left(\left(\mathrm{Au}_{24} \mathrm{Pt}\right)_{1-3}\right)$ occurred during calcination (Figure 15), probably because of the weak interaction between $\mathrm{Au}_{24} \mathrm{Pt}(\mathrm{PET})_{18-y}(p-\mathrm{MBA})_{y}$ and $\mathrm{Cr}_{2} \mathrm{O}_{3}$. The increase in the diameter decreases the surface energy of the metal cluster. ${ }^{7}$ This seems to be the reason why the metal clusters were not be covered by a chromium oxide shell after removal of the ligands by calcination. According to our previous study, part of the chromium oxide in the calcined photocatalyst is oxidized to higher than $\mathrm{Cr}^{3+}{ }^{6}$ Such chromium oxide with higher oxidation states can be reduced to $\mathrm{Cr}^{3+}$ by irradiation with a high-pressure $\mathrm{Hg}$ lamp (400 W) in aqueous solution. The obtained photocatalyst was then irradiated with a high-pressure $\mathrm{Hg}$ lamp to reduce the chromium oxide to $\mathrm{Cr}^{3+}$. This process also led to formation of a $\mathrm{Cr}_{2} \mathrm{O}_{3}$ shell on $\left(\mathrm{Au}_{24} \mathrm{Pt}\right)_{1-3}$, probably because of the decrease in the surface energy of chromium oxide. In this way, we obtained $\left(\mathrm{Au}_{24} \mathrm{Pt}\right)_{1-3}-$ $\mathrm{Cr}_{2} \mathrm{O}_{3}-\mathrm{BaLa}_{4} \mathrm{Ti}_{4} \mathrm{O}_{15}$ in which $\left(\mathrm{Au}_{24} \mathrm{Pt}\right)_{1-3}$ was covered by a $\mathrm{Cr}_{2} \mathrm{O}_{3}$ shell (top of Figure 15). 


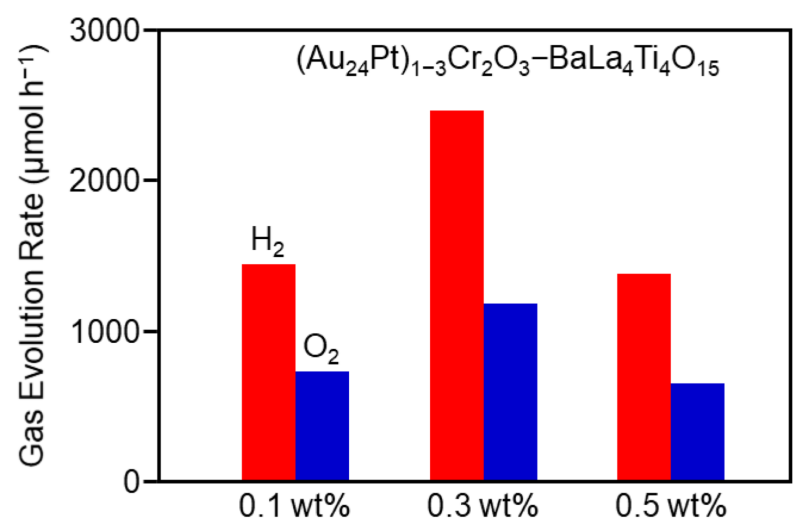

Figure S26. Gas evolution rates of $\mathrm{H}_{2}$ and $\mathrm{O}_{2}$ over $\left(\mathrm{Au}_{24} \mathrm{Pt}\right)_{1-3}-\mathrm{Cr}_{2} \mathrm{O}_{3}-\mathrm{BaLa}_{4} \mathrm{Ti}_{4} \mathrm{O}_{15}$ with different $\mathrm{Cr}$ contents. $\left(\mathrm{Au}_{24} \mathrm{Pt}\right)_{1-3}-\mathrm{Cr}_{2} \mathrm{O}_{3}-\mathrm{BaLa}_{4} \mathrm{Ti}_{4} \mathrm{O}_{15}$ with $0.3 \mathrm{wt} \% \mathrm{Cr}$ exhibits the highest activity.

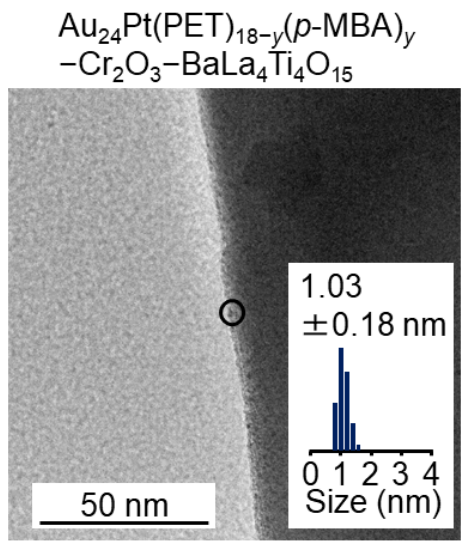

Figure S27. TEM image of $\mathrm{Au}_{24} \mathrm{Pt}(\mathrm{PET})_{18-y}(p-\mathrm{MBA})_{y}-\mathrm{Cr}_{2} \mathrm{O}_{3}-\mathrm{BaLa}_{4} \mathrm{Ti}_{4} \mathrm{O}_{15}$. The metal cluster is surrounded by the black circle. 


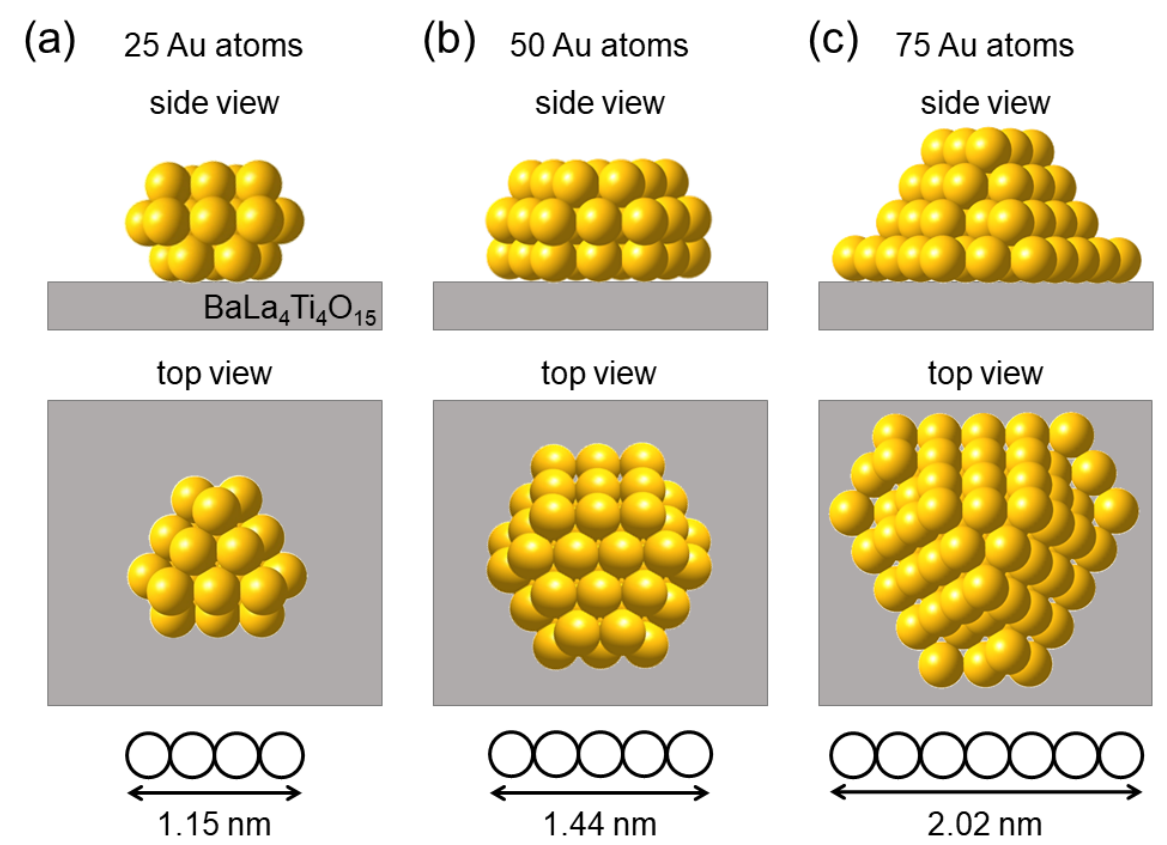

Figure S28. Proposed diameters of the metal clusters composed of (a) $25 \mathrm{Au}$, (b) $50 \mathrm{Au}$, and (c) $75 \mathrm{Au}$ atoms. These geometrical structures are just models and not the experimentally elucidated structures. In this model, the radius of $\mathrm{Au}$ is fixed to $1.44 \AA{ }^{8}{ }^{8}$ On the basis of these proposed structures, it is estimated that $\mathrm{Au}_{24} \mathrm{Pt},\left(\mathrm{Au}_{24} \mathrm{Pt}\right)_{2}$, and $\left(\mathrm{Au}_{24} \mathrm{Pt}\right)_{3}$ have ratios of $39.0 \%, 55.8 \%$, and $5.2 \%$, respectively, in the sample of $\left(\mathrm{Au}_{24} \mathrm{Pt}\right)_{1-3}-\mathrm{Cr}_{2} \mathrm{O}_{3}-\mathrm{BaLa}_{4} \mathrm{Ti}_{4} \mathrm{O}_{15}$ (top of Figure 15).

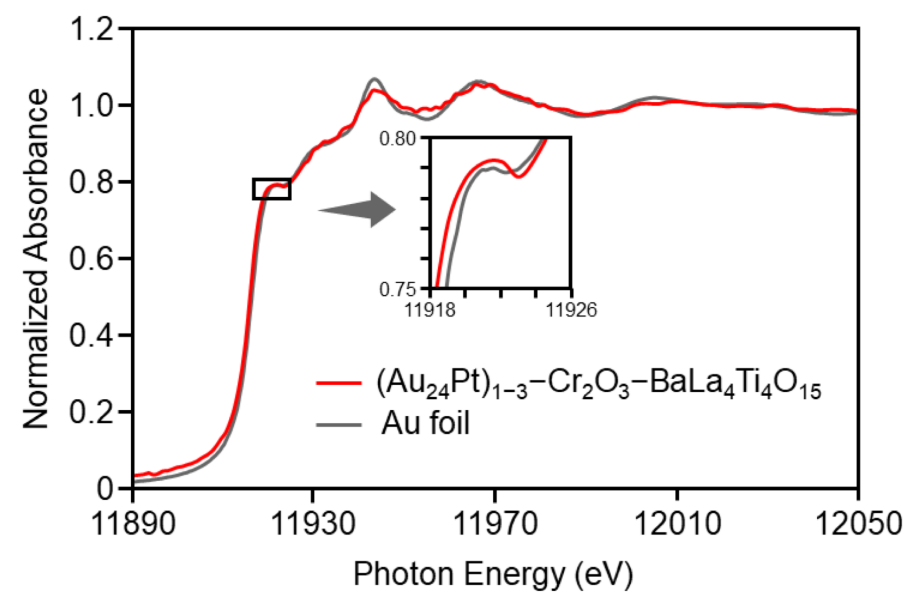

Figure S29. $\mathrm{Au} \mathrm{L} \mathrm{L}_{3}$-edge XANES spectrum of $\left(\mathrm{Au}_{24} \mathrm{Pt}\right)_{1-3}-\mathrm{Cr}_{2} \mathrm{O}_{3}-\mathrm{BaLa}_{4} \mathrm{Ti}_{4} \mathrm{O}_{15}$ together with that of $\mathrm{Au}$ foil. Comparison of this spectrum with Figure 12 indicates that the Au charge state is slightly different in $\left(\mathrm{Au}_{24} \mathrm{Pt}\right)_{1-3}-\mathrm{Cr}_{2} \mathrm{O}_{3}-\mathrm{BaLa}_{4} \mathrm{Ti}_{4} \mathrm{O}_{15}$ than in $\mathrm{Au}_{24} \mathrm{Pt}-\mathrm{BaLa}_{4} \mathrm{Ti}_{4} \mathrm{O}_{15}$. 


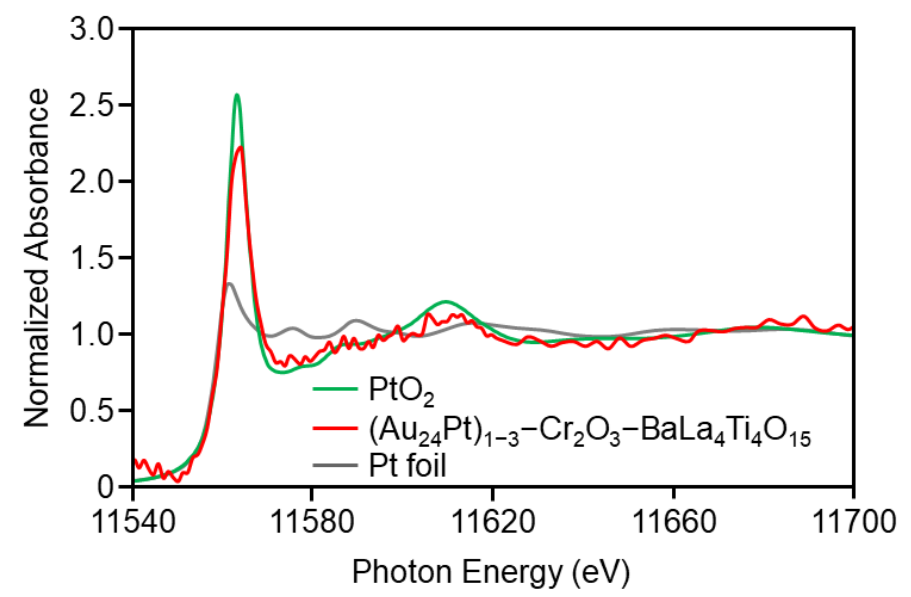

Figure S30. $\mathrm{Pt} \mathrm{L}_{3}$-edge XANES spectrum of $\left(\mathrm{Au}_{24} \mathrm{Pt}\right)_{1-3}-\mathrm{Cr}_{2} \mathrm{O}_{3}-\mathrm{BaLa}_{4} \mathrm{Ti}_{4} \mathrm{O}_{15}$ together with that of $\mathrm{Pt}$ foil. This spectrum indicates that $\mathrm{Pt}$ in $\left(\mathrm{Au}_{24} \mathrm{Pt}\right)_{1-3}-\mathrm{Cr}_{2} \mathrm{O}_{3}-\mathrm{BaLa}_{4} \mathrm{Ti}_{4} \mathrm{O}_{15}$ also bonds with $\mathrm{O}$, although it is difficult to determine which $\mathrm{O}\left(\mathrm{O}\right.$ in $\mathrm{BaLa}_{4} \mathrm{Ti}_{4} \mathrm{O}_{15}$ or $\mathrm{O}$ in $\left.\mathrm{Cr}_{2} \mathrm{O}_{3}\right)$ bonds with $\mathrm{Pt}$.

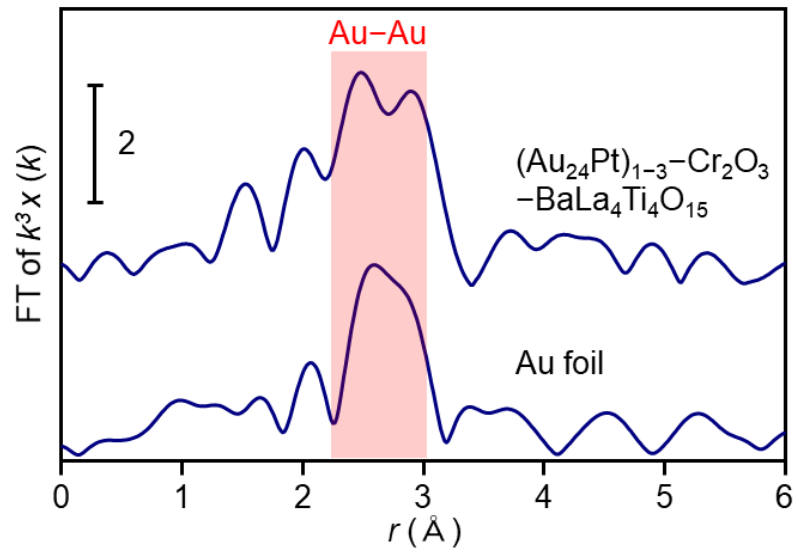

Figure S31. Au L $\mathrm{L}_{3}$-edge FT-EXAFS spectrum of $\left(\mathrm{Au}_{24} \mathrm{Pt}_{1-3}-\mathrm{Cr}_{2} \mathrm{O}_{3}-\mathrm{BaLa}_{4} \mathrm{Ti}_{4} \mathrm{O}_{15}\right.$ together with that of $\mathrm{Au}$ foil. The peak assigned to the $\mathrm{Au}-\mathrm{S}$ bond $(\sim 1.8 \AA)^{9}$ is hardly observed in the FT-EXAFS spectrum of $\left(\mathrm{Au}_{24} \mathrm{Pt}\right)_{1-3}-\mathrm{Cr}_{2} \mathrm{O}_{3}-\mathrm{BaLa}_{4} \mathrm{Ti}_{4} \mathrm{O}_{15}$, indicating that the ligands are eliminated in $\left(\mathrm{Au}_{24} \mathrm{Pt}_{1-3}-\mathrm{Cr}_{2} \mathrm{O}_{3}-\right.$ $\mathrm{BaLa}_{4} \mathrm{Ti}_{4} \mathrm{O}_{15}$. 


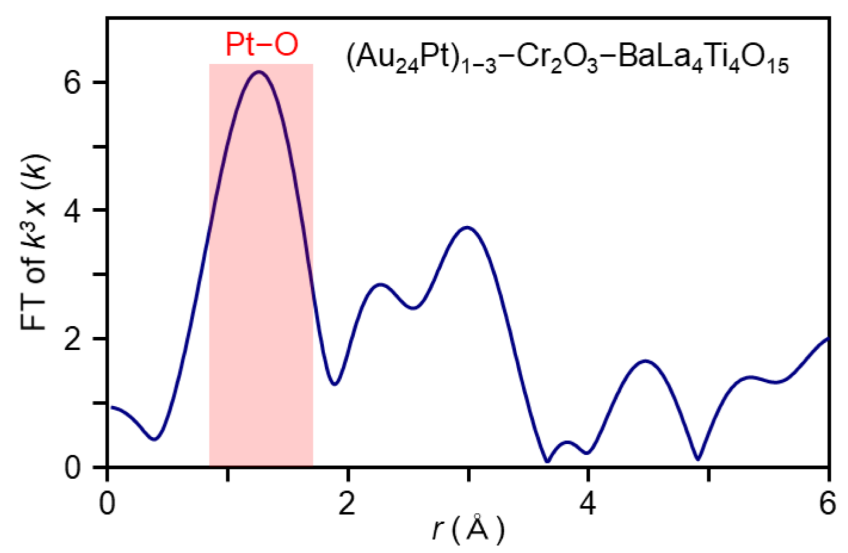

Figure S32. $\mathrm{Pt} \mathrm{L}_{3}$-edge FT-EXAFS spectrum of $\left(\mathrm{Au}_{24} \mathrm{Pt}\right)_{1-3}-\mathrm{Cr}_{2} \mathrm{O}_{3}-\mathrm{BaLa}_{4} \mathrm{Ti}_{4} \mathrm{O}_{15}$. The pink region indicates the peak position assigned to the $\mathrm{Pt}-\mathrm{O}$ bond. This FT-EXAFS spectrum indicates that the $\mathrm{Pt}-\mathrm{O}$ bond(s) is (are) formed in $\left(\mathrm{Au}_{24} \mathrm{Pt}\right)_{1-3}-\mathrm{Cr}_{2} \mathrm{O}_{3}-\mathrm{BaLa}_{4} \mathrm{Ti}_{4} \mathrm{O}_{15}$, which is consistent with the result obtained from the $\mathrm{Pt}$ $\mathrm{L}_{3}$-edge XANES spectrum (Figure S29).

\section{(A)}
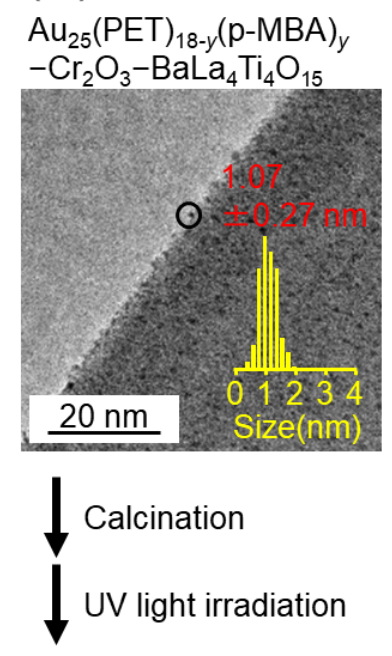

$\left(\mathrm{Au}_{25}\right)_{1-n}-\mathrm{Cr}_{2} \mathrm{O}_{3}$ $-\mathrm{BaLa}_{4} \mathrm{Ti}_{4} \mathrm{O}_{15}$

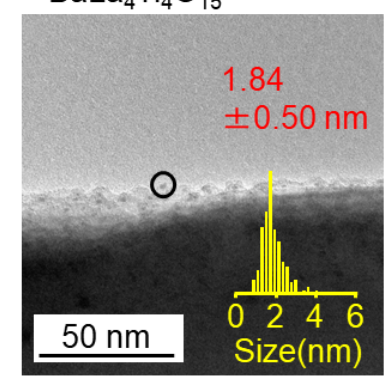

(B)

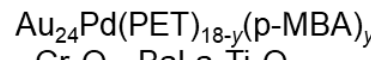

$-\mathrm{Cr}_{2} \mathrm{O}_{3}-\mathrm{BaLa}_{4} \mathrm{Ti}_{4} \mathrm{O}_{15}$
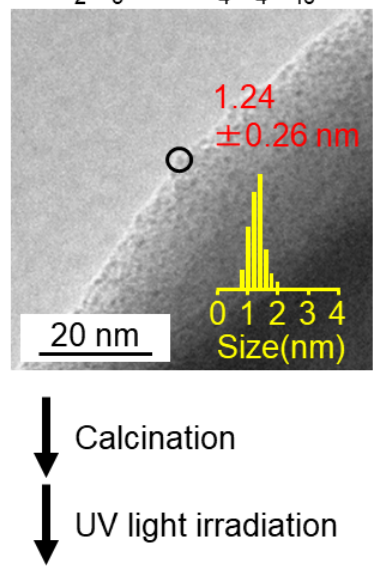

$\left(\mathrm{Au}_{24} \mathrm{Pd}\right)_{1-n}-\mathrm{Cr}_{2} \mathrm{O}_{3}$

$-\mathrm{BaLa}_{4} \mathrm{Ti}_{4} \mathrm{O}_{15}$

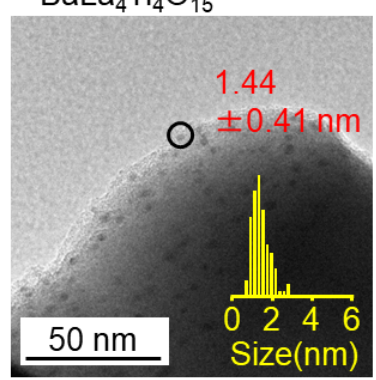

(C)

$\mathrm{Au}_{24} \mathrm{Pt}(\mathrm{PET})_{18-y}(\mathrm{p}-\mathrm{MBA})_{y}$

$-\mathrm{Cr}_{2} \mathrm{O}_{3}-\mathrm{BaLa}_{4} \mathrm{Ti}_{4} \mathrm{O}_{15}$

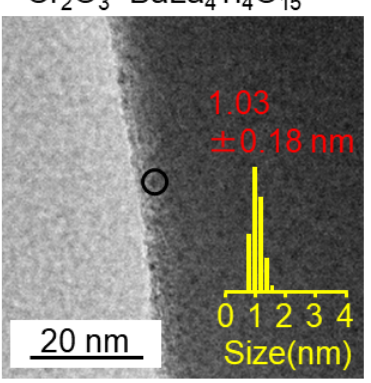

Calcination

UV light irradiation

$\left(\mathrm{Au}_{24} \mathrm{Pt}\right)_{1-3}-\mathrm{Cr}_{2} \mathrm{O}_{3}$ $-\mathrm{BaLa}_{4} \mathrm{Ti}_{4} \mathrm{O}_{15}$

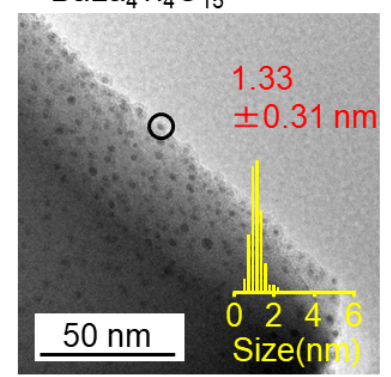

Figure S33. Comparison of TEM image before and after the formation of $\mathrm{Cr}_{2} \mathrm{O}_{3}$ shell; (a) $\mathrm{Au}_{25}-\mathrm{Cr}_{2} \mathrm{O}_{3}-$ $\mathrm{BaLa}_{4} \mathrm{Ti}_{4} \mathrm{O}_{15}$, (b) $\mathrm{Au}_{24} \mathrm{Pd}-\mathrm{Cr}_{2} \mathrm{O}_{3}-\mathrm{BaLa}_{4} \mathrm{Ti}_{4} \mathrm{O}_{15}$, and (c) $\mathrm{Au}_{24} \mathrm{Pt}-\mathrm{Cr}_{2} \mathrm{O}_{3}-\mathrm{BaLa}_{4} \mathrm{Ti}_{4} \mathrm{O}_{15}$. The metal clusters are surrounded by the black circles. A little aggregation of the metal clusters occurred during the $\mathrm{Cr}_{2} \mathrm{O}_{3}$ shell formation. 


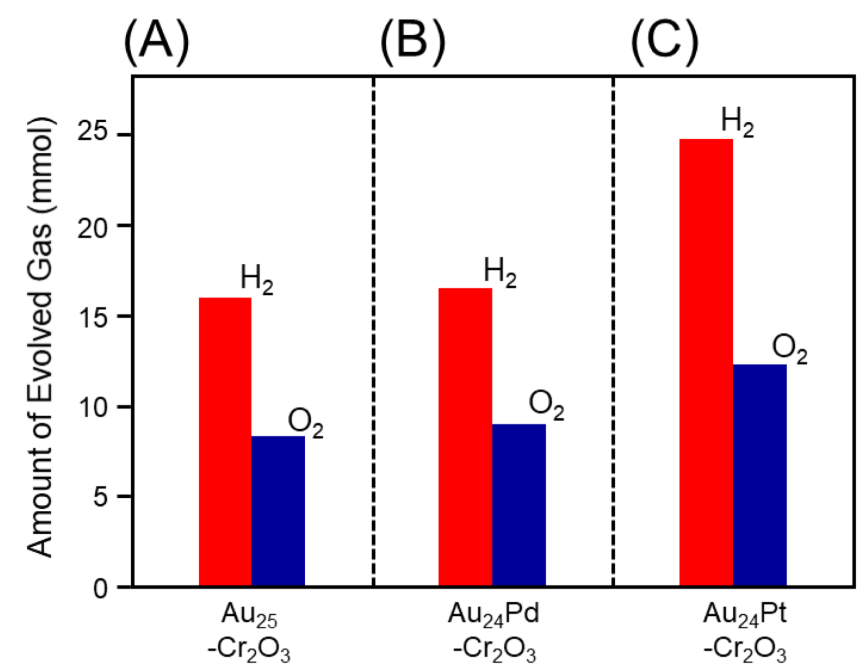

Figure S34. Comparison of amounts of evolved gas during the 10 hours over (a) $\mathrm{Au}_{25}-\mathrm{Cr}_{2} \mathrm{O}_{3}-\mathrm{BaLa}_{4} \mathrm{Ti}_{4} \mathrm{O}_{15}$, (b) $\mathrm{Au}_{24} \mathrm{Pd}-\mathrm{Cr}_{2} \mathrm{O}_{3}-\mathrm{BaLa}_{4} \mathrm{Ti}_{4} \mathrm{O}_{15}$, and (c) $\mathrm{Au}_{24} \mathrm{Pt}-\mathrm{Cr}_{2} \mathrm{O}_{3}-\mathrm{BaLa}_{4} \mathrm{Ti}_{4} \mathrm{O}_{15}$. The amount of evolved gas over $\mathrm{Au}_{24} \mathrm{Pd}-\mathrm{Cr}_{2} \mathrm{O}_{3}-\mathrm{BaLa}_{4} \mathrm{Ti}_{4} \mathrm{O}_{15}$ was lower than that over $\mathrm{Au}_{24} \mathrm{Pt}_{-}-\mathrm{Cr}_{2} \mathrm{O}_{3}-\mathrm{BaLa}_{4} \mathrm{Ti}_{4} \mathrm{O}_{15}$ regardless of the similar $\mathrm{H}_{2}$ evolution ability (Figure 14). This is probably caused by the aggregation of the metal clusters during the $\mathrm{Cr}_{2} \mathrm{O}_{3}$ shell formation (Figure $\mathrm{S} 32$ ).

\section{References}

(1) Miseki, Y.; Kato, H.; Kudo, A. Water Splitting into $\mathrm{H}_{2}$ and $\mathrm{O}_{2}$ over Niobate and Titanate Photocatalysts with (111) Plane-Type Layered Perovskite Structure. Energy Environ. Sci. 2009, 2, 306-314.

(2) Zhu, M.; Aikens, C. M.; Hollander, F. J.; Schatz, G. C.; Jin, R. Correlating the Crystal Structure of a ThiolProtected $\mathrm{Au}_{25}$ Cluster and Optical Properties. J. Am. Chem. Soc. 2008, 130, 5883-5885.

(3) Tofanelli, M. A.; Ni, T. W.; Phillips, B. D.; Ackerson, C. J. Crystal Structure of the PdAu ${ }_{24}(\mathrm{SR})_{18}{ }^{0}$ Superatom. Inorg. Chem. 2016, 55, 999-1001.

(4) Qian, H.; Jiang, D.-e.; Li, G.; Gayathri, C.; Das, A.; Gil, R. R.; Jin, R. Monoplatinum Doping of Gold Nanoclusters and Catalytic Application. J. Am. Chem. Soc. 2012, 134, 16159-16162.

(5) Niihori, Y.; Eguro, M.; Kato, A.; Sharma, S.; Kumar, B.; Kurashige, W.; Nobusada, K.; Negishi, Y. Improvements in the Ligand-Exchange Reactivity of Phenylethanethiolate-Protected $\mathrm{Au}_{25}$ Nanocluster by Ag or Cu Incorporation. J. Phys. Chem. C 2016, 120, 14301-14309.

(6) Kurashige, W.; Kumazawa, R.; Ishii, D.; Hayashi, R.; Niihori, Y.; Hossain, S.; Nair, L. V.; Takayama, T.; Iwase, A.; Yamazoe, S.; Tsukuda, T.; Kudo, A.; Negishi, Y. $\mathrm{Au}_{25}$-Loaded BaLa $\mathrm{Ci}_{4} \mathrm{O}_{15}$ Water-Splitting Photocatalyst with Enhanced Activity and Durability Produced Using New Chromium Oxide Shell Formation Method. J. Phys. Chem. C 2018, 122, 13669-13681.

(7) Ma, F.; Xu, K.-W. Using Dangling Bond Density to Characterize the Surface Energy of Nanomaterials. Surf. Interface Anal. 2007, 39, 611-614.

(8) Ferrando, R.; Jellinek, J.; Johnston, R. L. Nanoalloys: From Theory to Applications of Alloy Clusters and Nanoparticles. Chem. Rev. 2008, 108, 845-910.

(9) Yamazoe, S.; Takano, S.; Kurashige, W.; Yokoyama, T.; Nitta, K.; Negishi, Y.; Tsukuda, T. Hierarchy of Bond Stiffnesses within Icosahedral-Based Gold Clusters Protected by Thiolates. Nat. Commun. 2016, 7 , 10414. 